University of Nebraska - Lincoln

DigitalCommons@University of Nebraska - Lincoln

1999

\title{
Areas Susceptible to Irrigation-Induced Selenium Contamination of Water and Biota in the Western United States
}

\author{
Ralph L. Seiler \\ U.S. Geological Survey \\ Joseph P. Skorupa \\ U.S. Geological Survey \\ Lorri A. Peltz \\ U.S. Geological Survey
}

Follow this and additional works at: https://digitalcommons.unl.edu/usgspubs

Part of the Earth Sciences Commons

Seiler, Ralph L.; Skorupa, Joseph P.; and Peltz, Lorri A., "Areas Susceptible to Irrigation-Induced Selenium Contamination of Water and Biota in the Western United States" (1999). Publications of the US Geological Survey. 84.

https://digitalcommons.unl.edu/usgspubs/84

This Article is brought to you for free and open access by the US Geological Survey at DigitalCommons@University of Nebraska - Lincoln. It has been accepted for inclusion in Publications of the US Geological Survey by an authorized administrator of DigitalCommons@University of Nebraska - Lincoln. 


\section{Areas Susceptible to Irrigation-Induced Selenium Contamination of Water and Biota in the Western United States}

U.S. GEOLOGICAL SURVEY CIRCULAR 1180

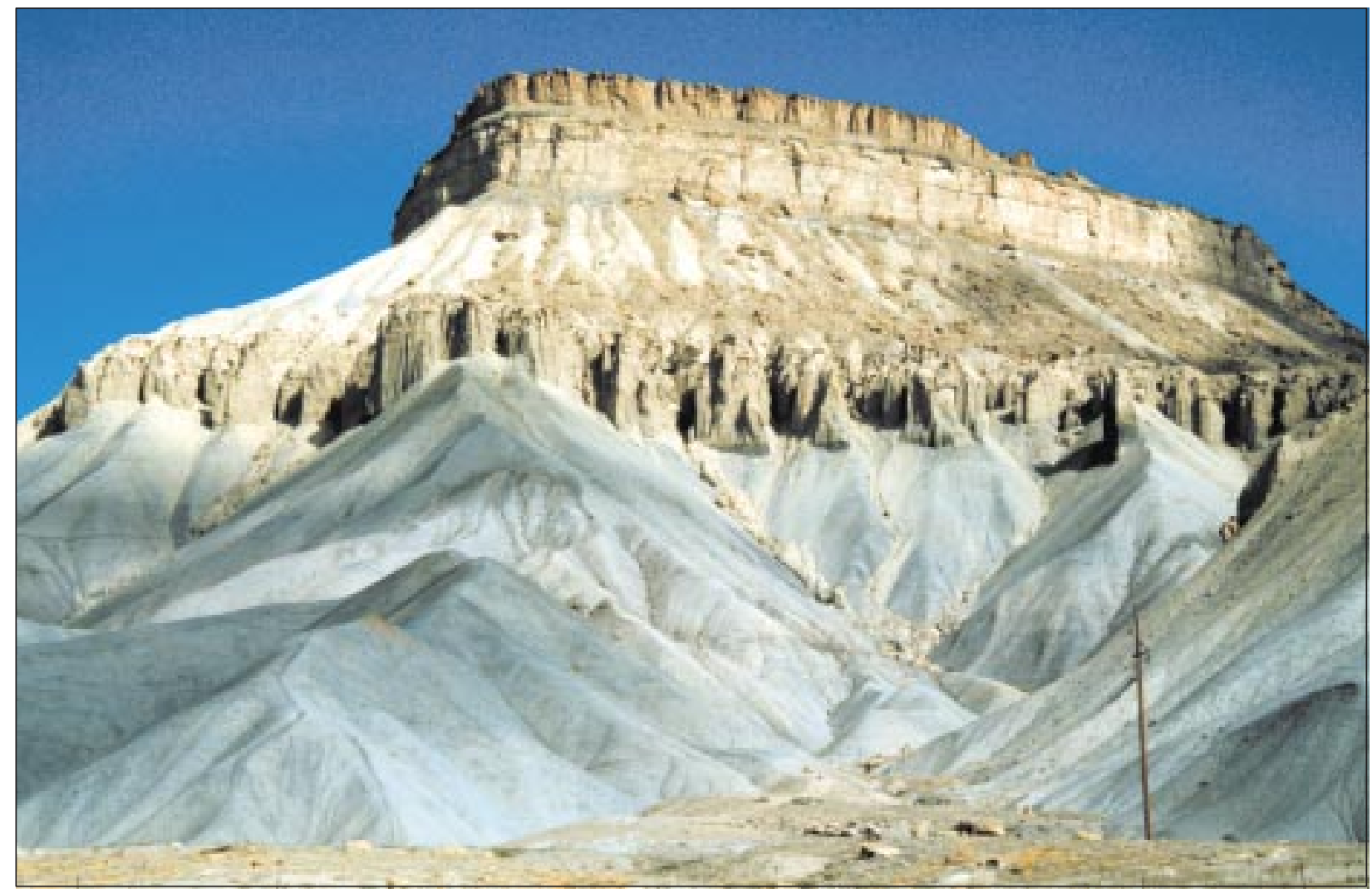

Marine rocks like those exposed at the base of Mount Garfield, Colo., are sources for trace elements in many irrigated areas of the Western United States. Photograph by James G. Crock, U.S. Geological Survey, 1992

\section{U.S. DEPARTM ENT OF THE INTERIOR}

Prepared in cooperation:

U.S. GEOLOGICAL SURVEY

U.S. FISH AND WILDLIFE SERVICE

BUREAU OF RECLAM ATION

BUREAU OF INDIAN AFFAIRS

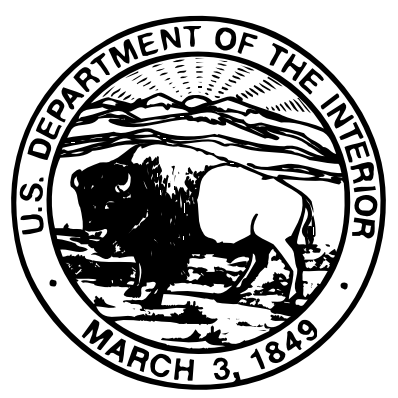




\section{Availability of Publications of the U.S. Geological Survey}

Order U.S. Geological Survey (USGS) publications from the offices listed below. Detailed ordering instructions, along with prices of the last offerings, are given in the current-year issues of the catalog "New Publications of the U.S. Geological Survey."

\section{Books, Maps, and Other Publications}

\section{By Mail}

Books, maps, and other publications are available by mail from-

USGS Information Services

Box 25286, Federal Center

Denver, CO 80225

Publications include Professional Papers, Bulletins, WaterSupply Papers, Techniques of Water-Resources Investigations, Circulars, Fact Sheets, publications of general interest, single copies of permanent USGS catalogs, and topographic and thematic maps.

\section{Over the Counter}

Books, maps, and other publications of the U.S. Geological Survey are available over the counter at the following USGS Earth Science Information Centers (ESIC's), all of which are authorized agents of the Superintendent of Documents:

- Anchorage, Alaska-Rm. 101, 4230 University Dr.

- Denver, Colorado-Bldg. 810, Federal Center

- Menlo Park, California-Rm. 3128, Bldg. 3, 345 Middlefield Rd.

- Reston, Virginia-Rm. 1C402, USGS National Center, 12201 Sunrise Valley Dr.

- Salt Lake City, Utah-2222 West, 2300 South (books and maps available for inspection only)

- Spokane, Washington-Rm. 135, U.S. Post Office Building, 904 West Riverside Ave.

- Washington, D.C.-Rm. 2650, Main Interior Bldg., 18th and C Sts., NW.

Maps only may be purchased over the counter at the following USGS office:

- Rolla, Missouri-1400 Independence Rd.

\section{Electronically}

Some USGS publications, including the catalog "New Publications of the U.S. Geological Survey" are also available electronically on the USGS's World Wide Web home page at http://www.usgs.gov

\section{Preliminary Determination of Epicenters}

Subscriptions to the periodical "Preliminary Determination of Epicenters" can be obtained only from the Superintendent of
Documents. Check or money order must be payable to the Superintendent of Documents. Order by mail from-

Superintendent of Documents

Government Printing Office

Washington, DC 20402

\section{Information Periodicals}

Many Information Periodicals products are available through the systems or formats listed below:

\section{Printed Products}

Printed copies of the Minerals Yearbook and the Mineral Commodity Summaries can be ordered from the Superintendent of Documents, Government Printing Office (address above). Printed copies of Metal Industry Indicators and Mineral Industry Surveys can be ordered from the Center for Disease Control and Prevention, National Institute for Occupational Safety and Health, Pittsburgh Research Center, P.O. Box 18070, Pittsburgh, PA 15236-0070.

\section{Mines FaxBack: Return fax service}

1. Use the touch-tone handset attached to your fax machine's telephone jack. (ISDN [digital] telephones cannot be used with fax machines.)

2. Dial (703) 648-4999.

3. Listen to the menu options and punch in the number of your selection, using the touch-tone telephone.

4. After completing your selection, press the start button on your fax machine.

\section{CD-ROM}

A disc containing chapters of the Minerals Yearbook (199395), the Mineral Commodity Summaries (1995-97), a statistical compendium (1970-90), and other publications is updated three times a year and sold by the Superintendent of Documents, Government Printing Office (address above).

\section{World Wide Web}

Minerals information is available electronically at http://minerals.er.usgs.gov/minerals/

\section{Subscription to the catalog "New Publications of the U.S. Geological Survey"}

Those wishing to be placed on a free subscription list for the catalog "New Publications of the U.S. Geological Survey" should write to-

U.S. Geological Survey

903 National Center

Reston, VA 20192 


\section{Areas Susceptible to Irrigation-Induced Selenium Contamination of Water and Biota in the Western United States}

By RALPH L. SEILER, JOSEPH P. SKORUPA, and LORRI A. PELTZ

Prepared in cooperation:

U.S. GEOLOGICAL SURVEY

U.S. FISH AND WILDLIFE SERVICE

BUREAU OF RECLAMATION

BUREAU OF INDIAN AFFAIRS

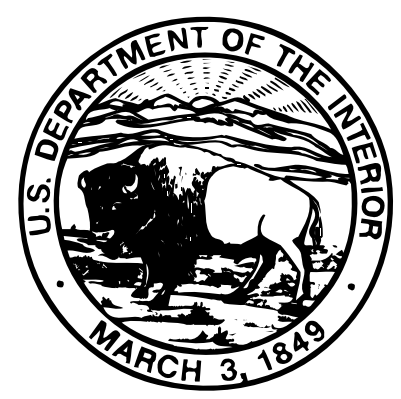

Carson City, Nevada 1999 


\title{
U.S. DEPARTMENT OF THE INTERIOR BRUCE BABBITT, Secretary
}

\author{
U.S. GEOLOGICAL SURVEY \\ Charles G. Groat, Director
}

Any use of trade, product, or firm names in this publication is for descriptive purposes only and does not imply endorsement by the U.S. Government

U.S. GOVERNMENT PRINTING OFFICE : 1999

\author{
Free on application to the \\ U.S. Geological Survey \\ Information Services \\ Box 25286 Federal Center \\ Denver, CO 80225
}

Library of Congress Cataloging-in-Publication Data

Seiler, R. L., 1948-

Areas susceptible to irrigation-induced selenium contamination of water and biota in the western United States / by Ralph L. Seiler, Joseph P. Skorupa, and Lorri A. Peltz.

p. $\quad$ cm. - (U.S. Geological Survey circular ; 1180)

Includes bibliographical references.

ISBN 0-607-92082-3

1. Selenium-Environmental aspects-West (U.S.) 2. IrrigationEnvironmental aspects-West (U.S.) 3. Geographic information systemsWest (U.S.) I. Skorupa, Joseph P., 1954- . II. Peltz, Lorri A. (Lorri Ann), 1959- III. Title. IV. Series.

QH545.S45S44 1999

$577.27^{\prime} 5724^{\prime} 0978-\mathrm{dc} 21$

99-29012 


\section{CONTENTS}

Abstract 1

Introduction 1

Background 1

Purpose and scope 2

Acknowledgments 2

Sources of selenium 2

Study methods $\mathbf{5}$

Physical classification of areas 7

Geology 7

Climate 7

Hydrology 11

Classification of study areas by selenium concentrations $\mathbf{1 2}$

Water 12

Biota 12

Use of geographic information system to create maps 14

Geologic data layers 14

Climatologic data layers $\mathbf{1 5}$

Land-use data layers 16

Factors affecting selenium concentrations in water $\mathbf{1 6}$

Geology 16

Climate 18

Hydrology 18

Deformities in aquatic birds and selenium concentrations in bird eggs 20

Map identifying areas susceptible to selenium contamination 21

Assessing map reliability $\mathbf{2 1}$

Test areas $\mathbf{2 1}$

Correctness of analysis 25

Accuracy and precision of maps 27

Land use within susceptible areas 28

Discussion and summary $\mathbf{2 8}$

References cited 32

\section{FIGURES}

1. Map of Western United States showing study areas and data-collection sites included in National Irrigation Water Quality Program 3

2. Map of Western United States showing areas where potentially seleniferous rocks form bedrock 6

3. Photograph showing Likes Lake, a shallow water body and wetland in an arid terminal basin northeast of Fallon, Nev. 11

4. Graph showing statistical summary of selenium concentrations in filtered surface water from 26 National Irrigation Water Quality Program study areas 13

5. Graph showing relations among selenium concentration, aridity, and geology for 26 National Irrigation Water Quality Program study areas 17

6. Map of Western United States showing areas where evaporation index is greater than $2.5 \quad \mathbf{1 9}$ 


\section{FIGURES}

7. Photograph of redhead duck embryos from middle Green River Basin study area in Utah, showing twisted bill and other deformities typical of those caused by selenium 20

8-12. Maps of Western United States showing:

8. Areas that are susceptible to irrigation-induced selenium contamination 22

9. National Irrigation Water Quality Program study areas, test areas, and areas that are susceptible to irrigation-induced selenium contamination 24

10. Bureau of Reclamation project areas in relation to areas that are susceptible to irrigation-induced selenium contamination $\quad 29$

11. National Wildlife Refuges in relation to areas that are susceptible to irrigation-induced selenium contamination $\mathbf{3 0}$

12. Irrigated agricultural land in relation to areas that are susceptible to irrigation-induced selenium contamination $\mathbf{3 1}$

\section{TABLES}

1. Reconnaissance and detailed studies concerning National Irrigation Water Quality Program study areas 4

2. Characteristics of National Irrigation Water Quality Program study areas $\mathbf{8}$

3. Generalized geology of National Irrigation Water Quality Program study areas $\mathbf{1 0}$

4. Geographic-information-system data layers used to create maps in this report 15

5. Western United States land areas where evaporation indexes exceed four threshold values 20

6. Western United States land areas where evaporation indexes exceed four threshold values and where bedrock consists of Upper Cretaceous or Tertiary marine sedimentary rocks $\mathbf{2 1}$

7. Reliability of map assessment of study-area susceptibility and interpolation of climatic variables $\mathbf{2 6}$

CONVERSION FACTORS AND ABBREVIATED WATER-QUALITY UNITS

\begin{tabular}{rcll}
\hline Multiply & By & To obtain \\
\hline acre & 4,047 & square meter \\
foot & 0.3048 & meter \\
inch & 25.4 & millimeter \\
mile & 1.609 & kilometer \\
square mile & 2.59 & square kilometer \\
\hline
\end{tabular}

Abbreviated water-quality units used in this report:

$\mu \mathrm{g} / \mathrm{L}$, microgram per liter

$\mu \mathrm{g} / \mathrm{g}$, microgram per gram

$\mathrm{mg} / \mathrm{kg}$, milligram per kilogram 


\title{
Areas Susceptible to Irrigation-Induced Selenium Contamination of Water and Biota in the Western United States
}

\author{
By RALPH L. SEILER, U.S. Geological Survey; JOSEPH P. SKORUPA, U.S. Fish and Wildlife \\ Service; and LORRI A. PELTZ, Nature Conservancy, formerly of U.S. Geological Survey
}

\begin{abstract}
The U.S. Department of the Interior (DOI) studied contamination induced by irrigation drainage in 26 areas of the Western United States during 1986-95. Comprehensive compilation, synthesis, and evaluation of the data resulting from these studies were initiated by DOI in 1992. Soils and ground water in irrigated areas of the West can contain high concentrations of selenium because of (1) residual selenium from the soil's parent rock beneath irrigated land; (2) selenium derived from rocks in mountains upland from irrigated land by erosion and transport along local drainages, and (3) selenium brought into the area in surface water imported for irrigation. Application of irrigation water to seleniferous soils can dissolve and mobilize selenium and create hydraulic gradients that cause the discharge of seleniferous ground water into irrigation drains. Given a source of selenium, the magnitude of selenium contamination in drainage-affected aquatic ecosystems is strongly related to the aridity of the area and the presence of terminal lakes and ponds. Marine sedimentary rocks and deposits of Late Cretaceous or Tertiary age are generally seleniferous in the Western United States. Depending on their origin and history, some Tertiary continental sedimentary deposits also are seleniferous. Irrigation of areas associated with these rocks and deposits can result in concentrations of selenium in water that exceed criteria for the protection of freshwater aquatic life.
\end{abstract}

Geologic and climatic data for the Western United States were evaluated and incorporated into a geographic information system (GIS) to produce a map identifying areas susceptible to irrigation-induced selenium contamination. Land is considered susceptible where a geologic source of selenium is in or near the area and where the evaporation rate is more than 2.5 times the precipitation rate. In the Western United
States, about 160,000 square miles of land, which includes about 4,100 square miles (2.6 million acres) of land irrigated for agriculture, has been identified as being susceptible. Biological data were used to evaluate the reliability of the map. In 12 of DOl's 26 study areas, concentrations of selenium measured in bird eggs were elevated sufficiently to significantly reduce hatchability of the eggs. The GIS map identifies 9 of those 12 areas. Deformed bird embryos having classic symptoms of selenium toxicosis were found in four of the study areas, and the map identifies all four as susceptible to irrigation-induced selenium contamination.

\section{INTRODUCTION}

\section{Background}

In 1983, incidents of mortality, congenital deformities, and reproductive failures in aquatic birds were discovered at Kesterson Reservoir, a U.S. Department of the Interior (DOI) National Wildlife Refuge in western San Joaquin Valley, Calif. The cause of these adverse biological effects was determined to be poisoning by selenium carried by irrigation drainage into areas used by wildlife (Ohlendorf and others, 1986, 1988). The U.S. Congress and environmental groups wanted to know if what happened at Kesterson Reservoir was an anomaly or if similar effects from irrigation drain water might occur elsewhere in the Nation. Therefore, in 1985, DOI implemented the National Irrigation Water Quality Program (NIWQP) to study the effects of irrigation drainage on water resources and on fish and wildlife (Deason, 1986). 
The DOI has constructed or manages more than 600 irrigation or irrigation-drainage facilities and National Wildlife Refuges in the 17 conterminous Western States. During 1985-86, the NIWQP screened existing data from these DOI facilities. As a result, 26 areas ( $A$ through $Z$ in fig. 1 and table $1)$ were selected for on-site reconnaissance investigations. After reconnaissance investigations confirmed that irrigation drainage had caused significant harmful effects on human health and on fish and wildlife, or otherwise had impaired beneficial uses of the water, detailed investigations were done in 9 of these 26 areas to determine the extent, magnitude, effects, and causes of contamination. NIWQP did the detailed investigations in eight of the nine areas $(F, H, I, N, U$, $V, W$, and $X$ ), and the remaining area $(Y)$ was studied under a separate Federal-State cooperative program (Moore and others, 1990).

U.S. Geological Survey publications describing results of investigations of the individual NIWQP study areas are listed in table 1. Some previous investigators (Sylvester and others, 1988; Feltz and others, 1991; Engberg and Sylvester, 1993; Presser and others, 1994; Seiler, 1995) evaluated data for some or all NIWQP study areas and observed that several factors determine the concentration of trace-element contaminants associated with irrigation drainage. Some of the more important factors are

- Pervasive geologic source of pertinent trace elements

- Arid to semiarid climate

- Topographically closed basin or sink.

Presser (1994b, p. 447) summarized 11 biogeochemical processes involved in the transport of selenium from rock to waterfowl at Kesterson Reservoir. Many of these processes probably occur in the areas that NIWQP found to be contaminated with selenium.

In 1992, NIWQP began a multiyear project to compile and evaluate information collected during completed as well as ongoing NIWQP investigations. The overall objective of the data synthesis is to identify physical factors and biogeochemical processes associated with irrigation-induced contamination of water and biota in the Western United States. Because selenium is the contaminant that most frequently exceeds water-quality criteria (Seiler, 1996), a secondary objective of the data synthesis has been to develop the ability to predict where irrigation-induced selenium contamination of water and biota is most likely.

\section{Purpose and Scope}

This report presents an analysis of data collected at the 26 areas in the Western United States that were investigated by the NIWQP from 1986 through 1995. Synthesis of these data resulted in a map that identifies areas in the Western United States which are susceptible to irrigation-induced selenium contamination. The map is intended to be used as a screening and ranking tool by managers. After ranking the likelihood of contamination in several areas, resources can be directed toward assessing selenium contamination in areas where it is most likely to occur. The reliability of the map is assessed by using biological and water-quality data collected for programs other than NIWQP.

\section{Acknowledgments}

George H. Taylor, Oregon State Climatologist, provided a preliminary data layer of precipitation in the United States based on a proprietary regression model. A. Dennis Lemly, U.S. Forest Service, and David L. Butler, U.S. Geological Survey (USGS), provided critical reviews that greatly improved the manuscript. Special thanks are due Theresa S. Presser and David Z. Piper, USGS, for sharing their thoughts on geological sources of selenium and the mechanisms by which rocks and soils become seleniferous. The authors thank the members of the U.S. Fish and Wildlife Service, Bureau of Reclamation, Bureau of Indian Affairs, and USGS who participated in the NIWQP investigations and provided detailed information about the study areas.

\section{SOURCES OF SEENIUM}

The sources and distribution of selenium-bearing soils in the Western United States were intensively researched during the 1930's and 1940's after the discovery that selenium in pasturage was the cause of a fatal disease afflicting cattle and horses. During 1968-75 the Bureau of Reclamation built the upper 85-mile reach of the San Luis Drain, which terminated at Kesterson Reservoir in the San Joaquin Valley in California (Tanji and others, 1986). By the 1960's, when the decisions were made to construct the drain and to use Kesterson Reservoir as its terminus, the awareness of selenium as a toxicant had faded. Early water-quality concerns focused instead on salinity, boron, nitrate, and pesticides (Tanji and others, 1986). The collapse of the warmwater fishery and the finding of deformed birds at Kesterson Reservoir in 1983 led to the rediscovery of selenium as an important environmental toxicant. Since then, intensive investigations have been made in the San Joaquin Valley and elsewhere to understand the sources of selenium. 


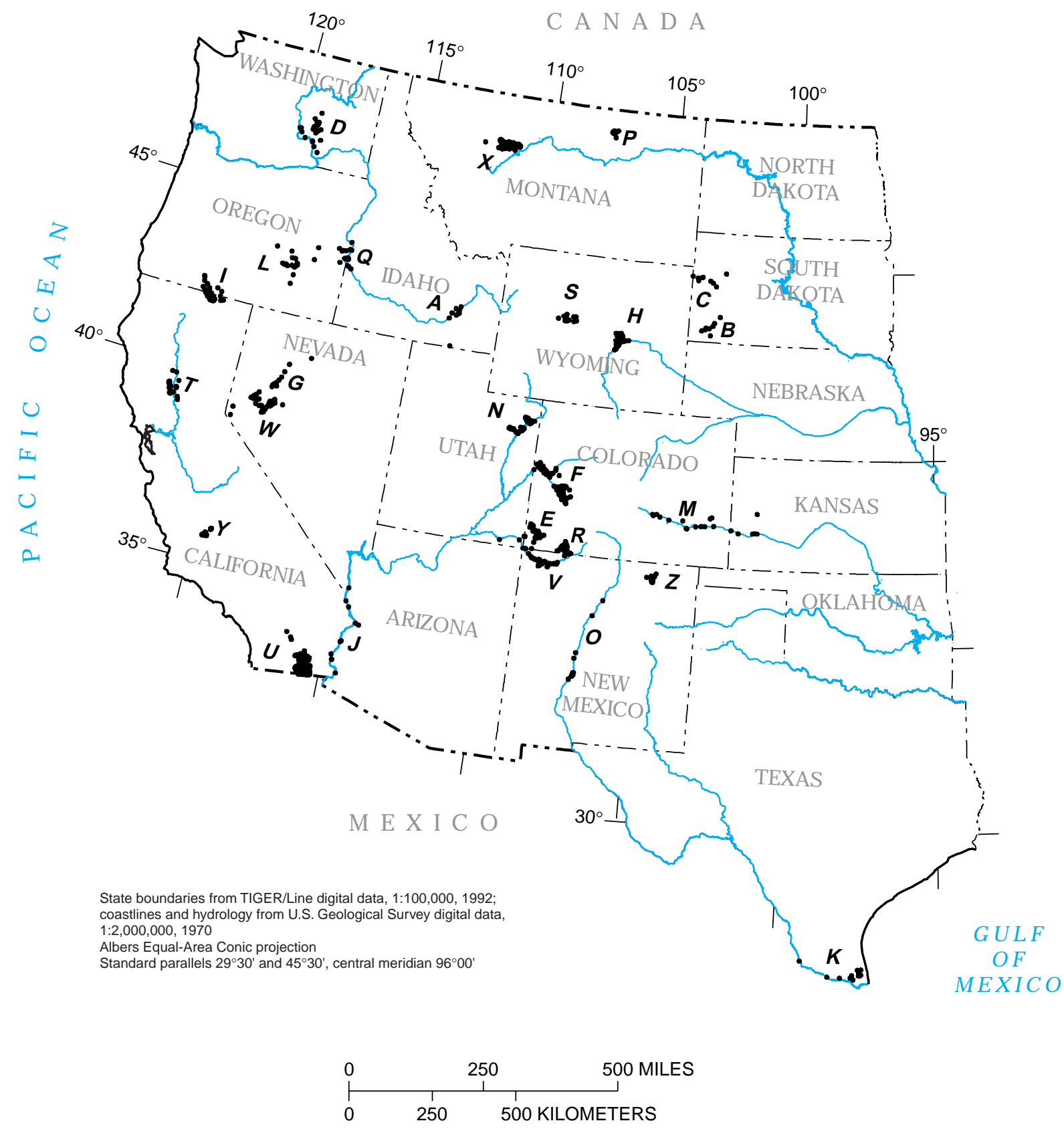

EXPLANATION

- $T$ Data-collection site for National Irrigation Water Q uality

Program study area-Letter is area identifier (table 2 )

Figure 1. Study areas and data-collection sites included in National Irrigation Water Quality Program. 
TABLE 1. Reconnaissance and detailed studies concerning National Irrigation Water Quality Program study areas

[Area identifier: See table 2 and figure 1. _, none]

\begin{tabular}{|c|c|c|c|}
\hline \multirow{2}{*}{$\begin{array}{l}\text { Area } \\
\text { identifier }\end{array}$} & \multirow{2}{*}{ Study area } & \multicolumn{2}{|c|}{ References } \\
\hline & & Reconnaissance studies & Detailed studies \\
\hline $\boldsymbol{A}$ & American Falls Reservoir, Idaho & Low and Mullins, 1990 & - \\
\hline$B$ & Angostura Reclamation Unit, South Dakota & Greene and others, 1990 & - \\
\hline C & Belle Fourche Reclamation Project, South Dakota & Roddy and others, 1991 & - \\
\hline$D$ & Columbia River Basin, Washington & Embry and Block, 1995 & - \\
\hline$E$ & Dolores-Ute Mountain area, Colorado & Butler and others, 1995 & - \\
\hline $\boldsymbol{F}$ & Gunnison River Basin-Grand Valley Project, Colorado & Butler and others, 1991 & Butler and others, 1994, 1996 \\
\hline G & Humboldt River area, Nevada & Seiler and others, 1993 & - \\
\hline$H$ & Kendrick Reclamation Project, Wyoming & Peterson and others, 1988 & $\begin{array}{l}\text { See, Naftz, and others, 1992; See, } \\
\text { Peterson, and Ramirez, } 1992 .\end{array}$ \\
\hline I & Klamath Basin Refuge Complex, California-Oregon & Sorenson and Schwarzbach, 1991 & $\begin{array}{l}\text { MacCoy, 1994; Dileanis and } \\
\text { others, } 1996\end{array}$ \\
\hline$J$ & Lower Colorado River valley, California-Arizona & Radtke and others, 1988 & - \\
\hline K & Lower Rio Grande valley, Texas & Wells and others, 1988 & - \\
\hline$L$ & Malheur National Wildlife Refuge, Oregon & Rinella and Schuler, 1992 & - \\
\hline$M$ & Middle Arkansas River Basin, Colorado-Kansas & Mueller and others, 1991 & - \\
\hline$N$ & Middle Green River Basin, Utah & Stephens and others, 1988 & $\begin{array}{l}\text { Peltz and Waddell, 1991; Stephens } \\
\text { and others, } 1992\end{array}$ \\
\hline 0 & Middle Rio Grande, New Mexico & Ong and others, 1992 & - \\
\hline $\boldsymbol{P}$ & Milk River Basin, Montana & Lambing and others, 1988 & - \\
\hline $\boldsymbol{Q}$ & Owyhee-Vale Reclamation Project areas, Oregon-Idaho & Rinella and others, 1994 & - \\
\hline $\boldsymbol{R}$ & Pine River area, Colorado & Butler and others, 1993 & - \\
\hline$s$ & Riverton Reclamation Project, Wyoming & Peterson and others, 1991 & - \\
\hline$T$ & Sacramento Refuge Complex, California & Dileanis and others, 1992 & - \\
\hline $\boldsymbol{U}$ & Salton Sea area, California & Setmire and others, 1990 & $\begin{array}{l}\text { Schroeder and others, 1993; } \\
\quad \text { Setmire and others, } 1993\end{array}$ \\
\hline $\boldsymbol{V}$ & San Juan River area, New Mexico & Blanchard and others, 1993 & Thomas and others, 1997 \\
\hline$w$ & Stillwater Wildlife Management Area, Nevada & Hoffman and others, 1990 & $\begin{array}{l}\text { Rowe and others, 1991; Lico, } \\
\text { 1992; Hallock and Hallock, } \\
\text { 1993; Hoffman, } 1994 .\end{array}$ \\
\hline$x$ & Sun River area, Montana & Knapton and others, 1988 & $\begin{array}{r}\text { Lambing and others, 1994; } \\
\text { Nimick and others, } 1996\end{array}$ \\
\hline $\boldsymbol{r}$ & Tulare Lake Bed area, California & Schroeder and others, 1988 & Moore and others, 1990 \\
\hline$z$ & Vermejo Project area, New Mexico & Bartolino and others, 1996 & - \\
\hline
\end{tabular}


Tidball and others (1991) noted that in the Diablo Range, along the west side of the San Joaquin Valley, Upper Cretaceous to Oligocene marine sedimentary rocks are variously seleniferous, whereas Pliocene and younger nonmarine sedimentary rocks generally are nonseleniferous. The importance of Cretaceous sedimentary rocks as sources of selenium in the Western United States has been known since the 1930's. Lakin and Byers (1941) summarized some of the research done during the 1930's and 1940's and concluded that "all areas of soils derived from material of Cretaceous age are then open to suspicion of the presence of harmful quantities of selenium ***." The regional importance of Upper Cretaceous marine sedimentary rocks as sources of selenium is indicated by their large areal extent; they form the bedrock beneath about 311,000 square miles of land in the 17 conterminous Western States (fig. 2).

Understanding general mechanisms of selenium distribution and enrichment in rocks of different types is important to identifying source areas. The selenium in marine sedimentary rocks may have been derived by direct deposition of particulate matter either from erosion of seleniferous deposits on the continental landmass or from fallout of seleniferous dusts and particles from the atmosphere. Several authors have proposed that oceans during Cretaceous time were enriched in selenium from volcanic activity (Byers and others, 1936; Berrow and Ure, 1989). Violent volcanic activity during Late Cretaceous time, when the Rocky Mountains began to rise, released selenium that was deposited in a large inland sea in what is now the Western United States (Trelease and Beath, 1949).

However, physical processes of selenium accumulation in marine sediments during Cretaceous time may have been of minor importance compared to biological processes. Presser (1994b) suggested that the bioaccumulation of selenium in the oceans and later deposition were primary mechanisms of selenium enrichment during the Cretaceous. Because bioaccumulation and deposition of seleniferous organic matter can occur even if selenium concentrations in oceans are not enriched by volcanic activity, any deposit laid down in a shallow, productive marine environment may be seleniferous.

Generally, Tertiary marine sedimentary deposits also are seleniferous. They contain selenium derived by bioaccumulation and particulate matter derived by the erosion of older (Cretaceous) seleniferous sedimentary deposits. Tertiary marine sedimentary deposits form the bedrock beneath almost 84,800 square miles of land in the Western United States (fig. 2). Presser (1994a) identified seleniferous marine formations of Upper Cretaceous-Paleocene, Eocene-Oligocene, and Miocene ages in the coast ranges of California.
Tertiary continental deposits derived from eroded Upper Cretaceous marine sedimentary rocks also may be seleniferous. Trelease and Beath (1949) identified several seleniferous formations of Tertiary age in Utah and Wyoming. However, they noted that sedimentary deposits of Tertiary age differ greatly in selenium content because of the diverse conditions that control deposition. Tertiary continental deposits form the bedrock beneath about 366,000 square miles of land in the Western United States (fig. 2).

Irrigation of seleniferous soils can dissolve and mobilize selenium and transport it in ground water into irrigation drains. Because drainage from agricultural areas is a major source of selenium in wildlife areas, the processes by which selenium is contributed to soils and ground water need to be understood. In most of the selenium-contaminated areas investigated by NIWQP, soils contain residual selenium from weathering of the parent rock. In the San Joaquin Valley, soils contain selenium that was brought in from seleniferous deposits in the surrounding mountains (Presser, 1994a,b). Thus, maps of bedrock geology can be used to identify areas having potentially seleniferous soils and ground water.

Soils and ground water in an area also can become seleniferous by surface-water transport of selenium from sources hundreds of miles upstream. For example, fish mortality in Martin Lake in east Texas (King and others, 1994) and Belews Lake in North Carolina (Lemly, 1985) has been attributed to selenium brought in from an industrial source; both reservoirs received seleniferous ash from nearby coalfired power plants. Also, the Colorado River transports both agriculturally and naturally derived selenium into the Imperial Valley in California, where the water is used for irrigation.

\section{STUDY MEIHODS}

The 26 study areas (fig. 1) were characterized by gathering geologic, hydrologic, climatologic, biologic, and chemical data in a relational database (Seiler, 1996). The data were analyzed to identify factors common to seleniumcontaminated areas, and a geographic information system (GIS) was used to map the spatial distribution of some of those factors. Biologic, geologic, climatologic, and hydrologic data, including information about water quality, are summarized in table 2. 


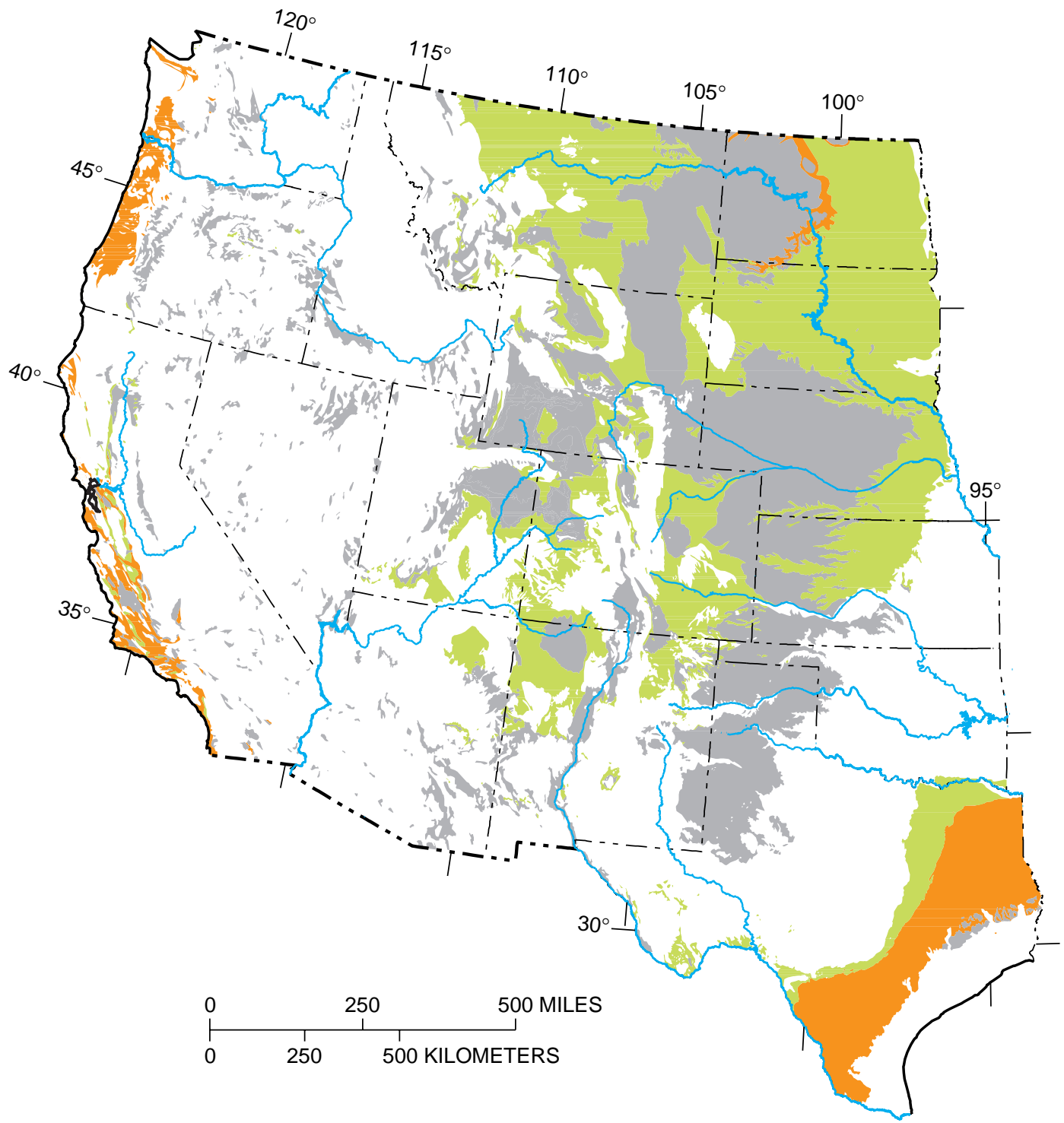

\section{EXPLANATION}

Tertiary marine sedimentary deposits

Tertiary continental sedimentary deposits

Upper Cretaceous marine sedimentary rocks

Figure 2. Areas in Western United States where potentially seleniferous rocks form bedrock. Geology from King and Beikman (1974a). For base credit, see figure 1. 


\section{Physical Classification of Areas}

\section{Geology}

Because the principal source of selenium in irrigated soils is residual selenium derived from the soil's parent material, knowledge of the geologic units underlying and surrounding irrigated land is very important. The King and Beikman (1974a) 1:2,500,000-scale geologic map of the United States was used as the source of geologic information about the 26 study areas. King and Beikman (1974b) noted that their national-scale geologic map would be used in planning activities in conjunction with other national maps showing environmental features such as climate and land use. For this report, using a small-scale geologic map for screening and ranking purposes is appropriate, although larger scale, more detailed geologic maps are available for individual study areas.

King and Beikman's (1974a) geologic-map units are listed for each study area in table 3; the units are ranked by the number of individual data-collection sites that are within a particular geologic unit in each study area. The most common geologic units in the study areas are Cretaceous to Quaternary marine or continental sedimentary deposits.

Potentially seleniferous geologic units were grouped into three main categories for this report. King and Beikman's (1974a) Upper Cretaceous stratified sedimentary sequences that were deposited mainly in marine environments are hereafter referred to as Upper Cretaceous marine sedimentary rocks or deposits; Paleocene to Pliocene, mainly marine, stratified sedimentary sequences are hereafter referred to as Tertiary marine sedimentary deposits; and Paleocene to Pliocene continental sedimentary deposits are hereafter referred to as Tertiary continental sedimentary deposits.

The 26 study areas were classified into groups primarily on the basis of their association or lack of association with Upper Cretaceous marine sedimentary rocks (table 2):

- Areas where most of the bedrock beneath irrigated lands consists of Upper Cretaceous marine sedimentary rocks

- Areas where the bedrock beneath irrigated lands is a combination of Upper Cretaceous marine sedimentary rocks and Tertiary continental sedimentary rocks
- Areas where the bedrock in mountains upland from irrigated lands includes Upper Cretaceous marine sedimentary rocks or includes both Upper Cretaceous and Tertiary marine sedimentary rocks

- Areas where rivers upstream from irrigated lands traverse Upper Cretaceous marine sedimentary rocks or both Upper Cretaceous and Tertiary marine sedimentary rocks

- Areas that are not associated with Upper Cretaceous marine sedimentary rocks.

The focus on Upper Cretaceous marine sedimentary rocks is because these rocks are known to be generally seleniferous and because they are common in the NIWQP study areas. NIWQP study areas containing Tertiary continental sedimentary deposits were not classified separately because in most instances they also are associated with Upper Cretaceous marine sedimentary rocks.

\section{Climate}

The amount of precipitation and the amount of water lost through evaporation are important factors in determining whether an area is susceptible to selenium contamination. The data on mean annual precipitation used in this report are from the reports that describe results of individual studies of the 26 areas (table 2). Where precipitation data for an area were reported as a range of values, the midpoint of the range was chosen to represent the precipitation in the area.

The evaporation rate used to characterize each of the 26 areas is the free-water-surface evaporation (FWSE) rate. The FWSE rate was chosen instead of the pan-evaporation rate because of the availability of a national map of FWSE rates, which ensures that a consistent method of quantifying the evaporation rates was applied to the 26 study areas. FWSE rates for the 26 areas were determined from evaporation maps of the United States prepared by Farnsworth and others (1982).

Precipitation and evaporation data were generalized into a single value to characterize the aridity of each of the 26 study areas and their potential for evaporative concentration of drain water. This value, herein called the evaporation index (EI), is the ratio of annual FWSE to mean annual precipitation. EI values for the 26 areas are listed in table 2. 
TABLE 2. Characteristics of National Irrigation Water Quality Program study areas

[C, contaminated; S, seleniferous; UC, uncontaminated; —, not sampled or not applicable; <, less than]

\begin{tabular}{|c|c|c|c|c|c|c|c|c|c|}
\hline \multirow{2}{*}{$\begin{array}{c}\text { Area } \\
\text { identifier }\end{array}$} & \multirow{2}{*}{ Study area } & \multicolumn{3}{|c|}{ Characteristics related to selenium contamination } & \multicolumn{2}{|c|}{$\begin{array}{l}\text { Selenium content of } \\
\text { surface water }{ }^{5} \\
\text { (micrograms per liter) }\end{array}$} & \multirow{2}{*}{$\begin{array}{l}\text { Study-area } \\
\text { classification }\end{array}$} & \multicolumn{2}{|c|}{ Avian egg sets } \\
\hline & & $\begin{array}{c}\text { Evaporation } \\
\text { index }^{2}\end{array}$ & $\begin{array}{c}\text { Selenium in } \\
\text { source water } \\
\text { (micrograms } \\
\text { per liter) }\end{array}$ & Geology ${ }^{4}$ & $\begin{array}{c}\text { 75th } \\
\text { percentile }\end{array}$ & Range & & $\begin{array}{c}\text { Number } \\
\text { of sets } \\
\text { sampled }\end{array}$ & $\begin{array}{c}\text { Maximum mean } \\
\text { selenium } \\
\text { concentration }\end{array}$ \\
\hline $\boldsymbol{A}$ & American Falls Reservoir, Idaho & 3.7 & - & $\begin{array}{l}\text { Irrigated lands are not associated with uK marine } \\
\text { sedimentary rocks. }\end{array}$ & 1 & $<1-6$ & $\mathrm{UC}$ & 7 & Normal \\
\hline$B$ & $\begin{array}{l}\text { Angostura Reclamation Unit, South } \\
\text { Dakota. }\end{array}$ & 2.8 & 2 & $\begin{array}{l}\text { Most of bedrock beneath irrigated lands consists of } \\
\text { uK marine sedimentary rocks. }\end{array}$ & 5 & $<1-6$ & S & 2 & Normal \\
\hline$c$ & $\begin{array}{l}\text { Belle Fourche Reclamation } \\
\text { Project, South Dakota. }\end{array}$ & 2.8 & 3 & $\begin{array}{l}\text { Most of bedrock beneath irrigated lands consists of } \\
\text { uK marine sedimentary rocks. }\end{array}$ & 5 & $2-11$ & $\mathrm{C}$ & 5 & Embryotoxic \\
\hline $\boldsymbol{D}$ & Columbia River Basin, Washington & 5.0 & $<1$ & $\begin{array}{l}\text { Irrigated lands are not associated with uK marine } \\
\text { sedimentary rocks. }\end{array}$ & $<1$ & $<1-4$ & $\mathrm{UC}$ & 7 & Elevated \\
\hline$E$ & $\begin{array}{l}\text { Dolores-Ute Mountain area, } \\
\text { Colorado. }\end{array}$ & 4.4 & $<1$ & $\begin{array}{l}\text { Most of bedrock beneath irrigated lands consists of } \\
\text { uK marine sedimentary rocks. }\end{array}$ & 7 & $<1-88$ & $\mathrm{C}$ & 10 & Embryotoxic \\
\hline $\boldsymbol{F}$ & $\begin{array}{l}\text { Gunnison River Basin-Grand } \\
\text { Valley Project, Colorado. }\end{array}$ & 5.4 & 9 & $\begin{array}{l}\text { Most of bedrock beneath irrigated lands consists of } \\
\text { uK marine sedimentary rocks. }\end{array}$ & 35 & $<1-380$ & $\mathrm{C}$ & 48 & Embryotoxic \\
\hline$G$ & Humboldt River area, Nevada & 8.1 & 1 & $\begin{array}{l}\text { Irrigated lands are not associated with uK marine } \\
\text { sedimentary rocks. }\end{array}$ & 2 & $<1-4$ & $\mathrm{UC}$ & 5 & Elevated \\
\hline$H$ & $\begin{array}{l}\text { Kendrick Reclamation Project, } \\
\text { Wyoming. }\end{array}$ & 3.7 & 2 & $\begin{array}{l}\text { Most of bedrock beneath irrigated lands consists of } \\
\text { uK marine sedimentary rocks. }\end{array}$ & 64 & $<1-5,300$ & $\mathrm{C}$ & 15 & Embryotoxic \\
\hline$I$ & $\begin{array}{l}\text { Klamath Basin Refuge Complex, } \\
\text { California-Oregon. }\end{array}$ & 3.0 & $<1$ & $\begin{array}{l}\text { Irrigated lands are not associated with uK marine } \\
\text { sedimentary rocks. }\end{array}$ & $<1$ & $<1-<1$ & $\mathrm{UC}$ & 5 & Normal \\
\hline$J$ & $\begin{array}{l}\text { Lower Colorado River valley, } \\
\text { California-Arizona. }\end{array}$ & 18.9 & 2 & $\begin{array}{l}\text { Rivers traverse uK marine sedimentary rocks } \\
\text { upstream from irrigated lands. }\end{array}$ & 2 & $<1-2$ & $\mathrm{UC}$ & 1 & Embryotoxic $^{9}$ \\
\hline$K$ & Lower Rio Grande valley, Texas & 2.2 & 1 & $\begin{array}{l}\text { Rivers traverse } \mathrm{uK} \text { and } \mathrm{T} \text { marine sedimentary rocks } \\
\text { upstream from irrigated lands. }\end{array}$ & 1 & $<1-2$ & $\mathrm{UC}$ & - & - \\
\hline$L$ & $\begin{array}{l}\text { Malheur National Wildlife Refuge, } \\
\text { Oregon. }\end{array}$ & 4.3 & $<1$ & $\begin{array}{l}\text { Irrigated lands are not associated with uK marine } \\
\text { sedimentary rocks. }\end{array}$ & $<1$ & $<1-<1$ & $\mathrm{UC}$ & 13 & Normal \\
\hline$M$ & $\begin{array}{l}\text { Middle Arkansas River Basin, } \\
\text { Colorado-Kansas. }\end{array}$ & 4.0 & 5 & $\begin{array}{l}\text { Most of bedrock beneath irrigated lands consists of } \\
\text { uK marine and T continental sedimentary rocks. }\end{array}$ & 10 & $2-52$ & $\mathrm{C}$ & 3 & Elevated \\
\hline$N$ & Middle Green River Basin, Utah & 5.7 & - & $\begin{array}{l}\text { Bedrock beneath irrigated lands consists of uK } \\
\text { marine and T continental sedimentary rocks. }\end{array}$ & 73 & $<1-8,300$ & $\mathrm{C}$ & 142 & Embryotoxic \\
\hline
\end{tabular}




\begin{tabular}{|c|c|c|c|c|c|c|c|c|c|}
\hline 0 & Middle Rio Grande, New Mexico & 6.8 & $<1$ & $\begin{array}{l}\text { Irrigated lands are not associated with uK marine } \\
\text { sedimentary rocks. }\end{array}$ & $<1$ & $<1-1$ & $\mathrm{UC}$ & 6 & Normal \\
\hline $\boldsymbol{P}$ & Milk River Basin, Montana & ${ }^{10} 1.9$ & $<1$ & $\begin{array}{l}\text { Most of bedrock beneath irrigated lands consists of } \\
\text { UK marine sedimentary rocks. }\end{array}$ & $<1$ & $<1-<1$ & $\mathrm{UC}$ & 3 & Normal \\
\hline $\boldsymbol{Q}$ & $\begin{array}{l}\text { Owyhee-Vale Reclamation Project } \\
\text { areas, Oregon-Idaho. }\end{array}$ & 4.5 & $<1$ & $\begin{array}{l}\text { Irrigated lands are not associated with uK marine } \\
\text { sedimentary rocks. }\end{array}$ & 2 & $<1-5$ & $\mathrm{UC}$ & 9 & Elevated \\
\hline $\boldsymbol{R}$ & Pine River area, Colorado & 3.5 & $<1$ & $\begin{array}{l}\text { Bedrock beneath irrigated lands consists of uK } \\
\text { marine and T continental sedimentary rocks. }\end{array}$ & 6 & $<1-94$ & $\mathrm{C}$ & 10 & Embryotoxic \\
\hline$s$ & $\begin{array}{l}\text { Riverton Reclamation Project, } \\
\text { Wyoming. }\end{array}$ & 4.9 & $<1$ & $\begin{array}{l}\text { Most of bedrock beneath irrigated lands consists } \\
\text { of T continental sedimentary rocks; bedrock in } \\
\text { mountains upland from irrigated lands includes } \\
\text { UK marine sedimentary rocks. }\end{array}$ & 5 & $<1-12$ & $\mathrm{C}$ & 7 & Embryotoxic \\
\hline$T$ & $\begin{array}{l}\text { Sacramento Refuge Complex, } \\
\text { California. }\end{array}$ & 2.6 & $<1$ & $\begin{array}{l}\text { Bedrock in mountains upland from irrigated lands } \\
\text { includes uK marine sedimentary rocks. }\end{array}$ & $<1$ & $<1-5$ & $\mathrm{UC}$ & 6 & Elevated \\
\hline $\boldsymbol{U}$ & Salton Sea area, California & 24.5 & 3 & $\begin{array}{l}\text { Rivers traverse uK marine sedimentary rocks } \\
\text { upstream from irrigated lands. }\end{array}$ & 8 & $<1-10$ & $\mathrm{C}$ & 9 & Elevated \\
\hline $\boldsymbol{V}$ & San Juan River area, New Mexico & 7.4 & $<1$ & $\begin{array}{l}\text { Bedrock beneath irrigated lands consists of uK } \\
\text { marine and } \mathrm{T} \text { continental sedimentary rocks. }\end{array}$ & 3 & $<1-67$ & $\mathrm{~S}$ & 9 & Embryotoxic \\
\hline$w$ & $\begin{array}{l}\text { Stillwater Wildlife Management } \\
\text { Area, Nevada. }\end{array}$ & 10.0 & $<1$ & $\begin{array}{l}\text { Irrigated lands are not associated with uK marine } \\
\text { sedimentary rocks. }\end{array}$ & $<1$ & $<1-21$ & $\mathrm{UC}$ & 29 & Embryotoxic \\
\hline$x$ & Sun River area, Montana & 3.0 & $<1$ & $\begin{array}{l}\text { Most of bedrock beneath irrigated lands consists of } \\
\text { UK marine sedimentary rocks. }\end{array}$ & 8 & $<1-190$ & $\mathrm{C}$ & 126 & Embryotoxic \\
\hline$Y$ & Tulare Lake Bed area, California & 11.1 & - & $\begin{array}{l}\text { Bedrock in mountains upland from irrigated lands } \\
\text { includes uK and T marine sedimentary rocks. }\end{array}$ & 265 & $<1-390$ & $\mathrm{C}$ & 132 & Embryotoxic \\
\hline$z$ & Vermejo Project area, New Mexico & 3.9 & 1 & $\begin{array}{l}\text { Most of bedrock beneath irrigated lands consists of } \\
\text { uK marine sedimentary rocks. }\end{array}$ & 6 & $<1-23$ & $\mathrm{C}$ & - & - \\
\hline
\end{tabular}

${ }^{1}$ Used in figure 1.

${ }^{2}$ Mean annual free-water-surface evaporation for area divided by mean annual precipitation.

${ }^{3}$ Maximum selenium concentration measured in surface-water body identified as providing water used for irrigation.

${ }^{4}$ Bedrock geology after King and Beikman (1974a). T, Tertiary; uK, Upper Cretaceous.

${ }^{5}$ Filtered surface water in and downstream from irrigated areas.

${ }^{6}$ Rounded to nearest microgram per liter.

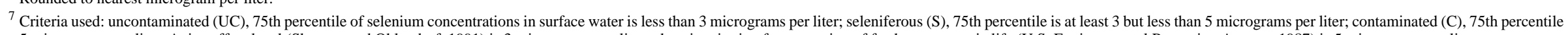

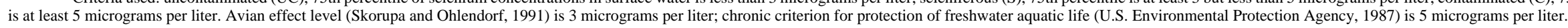

${ }^{8} \mathrm{Normal}$, less than or equal to 3 micrograms per gram; elevated, greater than 3 micrograms per gram but less than 8 micrograms per gram; embryotoxic, equal to or greater than 8 micrograms per gram.

${ }^{9}$ William G. Kepner, U.S. Fish and Wildlife Service (written commun., 1989).

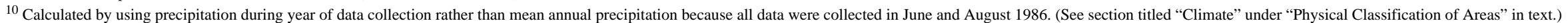


TABLE 3. Generalized geology of National Irrigation Water Quality Program study areas

[Geologic units within each study area are ranked according to relative number of individual data-collection sites (fig. 1) having the indicated geology. Geologic symbols and descriptions used are adapted from the compilation by King and Beikman (1974a). Generally in decreasingage order, these geologic units include Early Proterozoic igneous and metamorphic rocks (Xg, granitic rocks; Xm, orthogneiss and paragneiss); upper Paleozoic stratified, mainly marine, sedimentary rocks (uPz); Upper Cretaceous stratified, mainly marine, sedimentary rocks $\left(\mathrm{uK}_{1}\right.$, the Woodbine and Tuscaloosa Groups, locally including some Lower Cretaceous rocks not mapped separately; uK 2 , the Austin and Eagle Ford Groups; $\mathrm{uK}_{3}$, the Taylor Group; and $\mathrm{uK}_{4}$, the Navarro Group); Paleocene continental sedimentary deposits (Txc); Eocene continental sedimentary deposits ( $\mathrm{Tec}$ ); the Eocene Jackson Group $\left(\mathrm{Te}_{3}\right)$; Miocene volcanic rocks (Tmf, felsic; Tmv, nonfelsic); Pliocene continental sedimentary deposits (Tpc); Pliocene nonfelsic volcanic rocks (Tpv); thick and widespread Quaternary stratified sedimentary sequences (Q); Quaternary nonfelsic volcanic rocks (Qv); and Holocene stratified sedimentary deposits, Great Plains only (Qh). Geologic units exclude Pleistocene glacial deposits that blanket large parts of the northern interior States and are not shown on King and Beikman's (1974a) map]

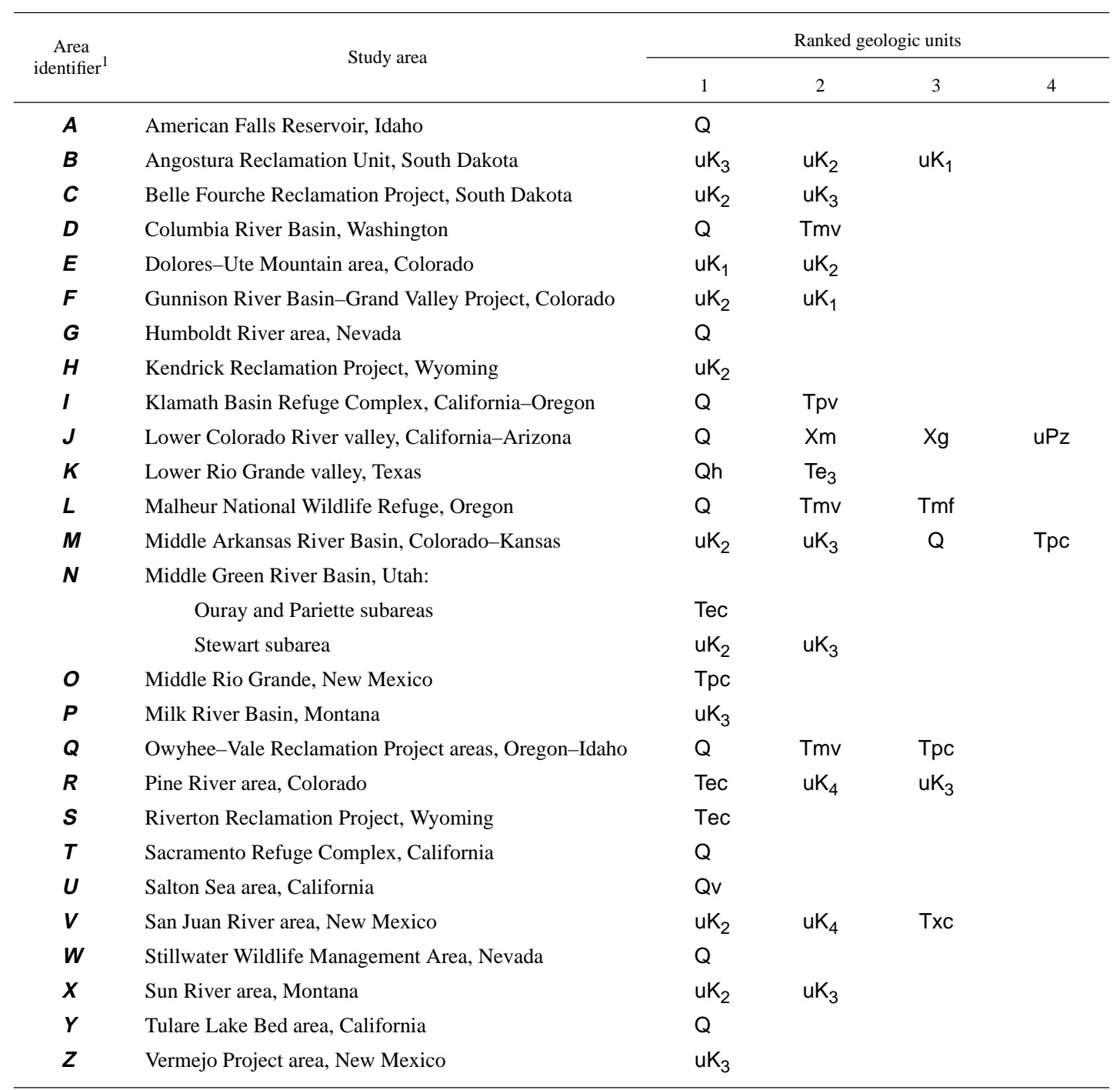

${ }^{1}$ Used in figure 1 ; also, see table 2. 
In two of the areas, Milk River Basin in Montana and Riverton Reclamation Project area in Wyoming (areas $P$ and $S$, table 2), all data were collected during a short period in a climatically unusual year. In the Milk River Basin, precipitation during the year of data collection was almost twice the normal amount. During the spring and early summer, prior to data collection during June and August, much more water than normal was delivered to the area, and therefore contaminants became diluted (Lambing and others, 1988). Precipitation during the year of data collection rather than the mean annual precipitation was used to calculate EI. In the Riverton Reclamation Project area, precipitation was less than half the normal amount, and temperatures (and evaporation) were above normal (Peterson and others, 1991). However, because of available water in storage, greater than normal irrigation-water deliveries were made to the area during the period of data collection (August and November 1986) to help offset the greater than normal evaporative losses. EI was calculated on the basis of the mean annual precipitation.

\section{Hydrology}

In terminal lakes (lakes without natural outlets; fig. 3), evaporation can result in very high concentrations of selenium because the solutes are retained and accumulated rather than flushed out. Areas were classified hydrologically as open basin or closed basin depending on whether they contain lakes or ponds that receive irrigation drain water and that are terminal during nonflood years (Seiler, 1995). Although these water bodies range from very large (the Salton Sea) to very small (unnamed stockponds or impoundments), size was not considered in the hydrologic classification.

Under certain circumstances, selenium contamination can occur in an area that has no local geologic sources of selenium because selenium is brought into the area from elsewhere. Maximum selenium concentrations observed in samples from water bodies identified as being sources of irrigation water exceeded or equaled $1 \mu \mathrm{g} / \mathrm{L}$ in 10 of the study areas (table 2). In 4 of the 10 areas, no local geologic sources

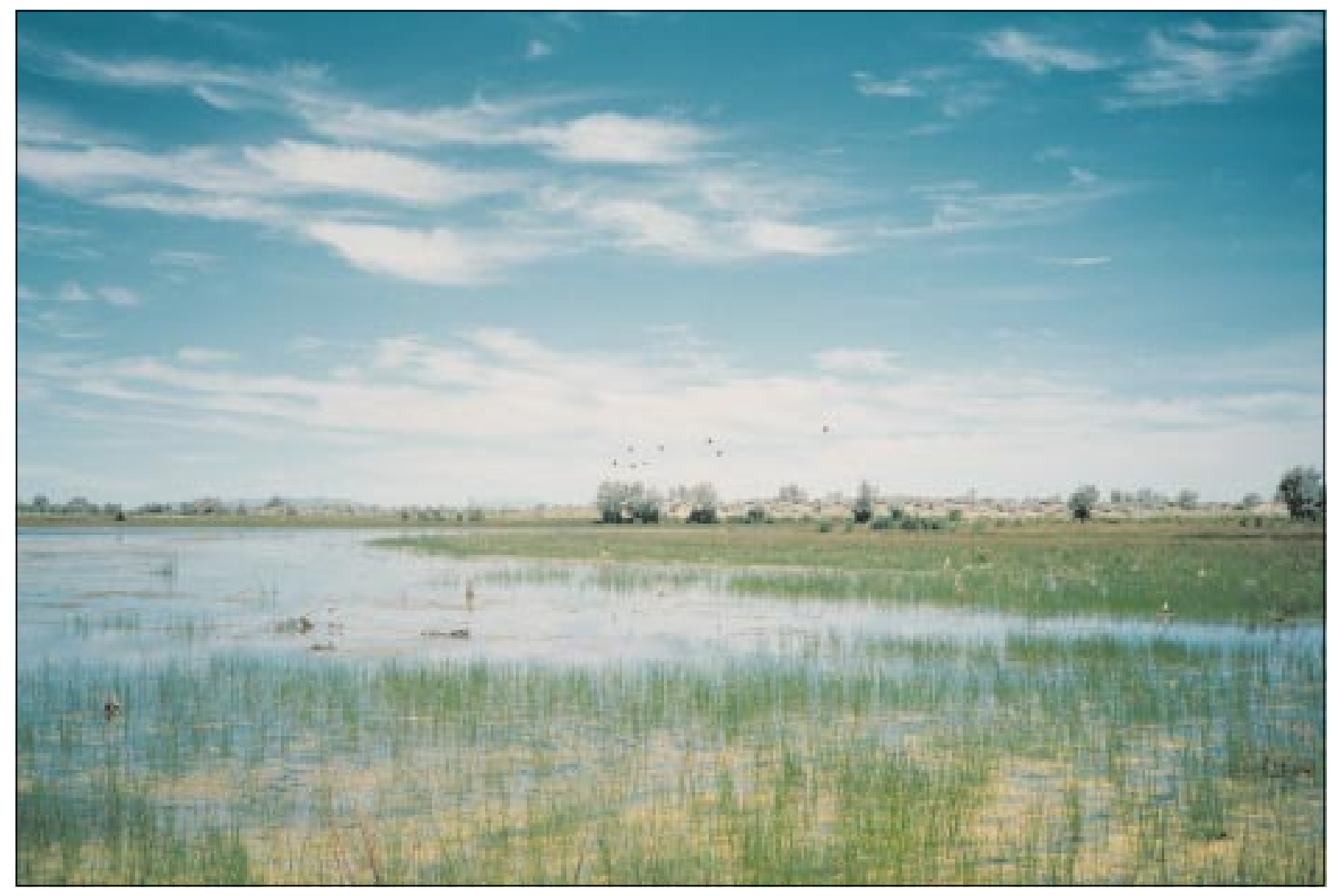

Figure 3. Likes Lake, a shallow water body and wetland in an arid terminal basin in the Stillwater Wildlife Management Area in Nevada. Such wetlands provide important feeding and nesting areas for migratory birds but commonly contain high salt and trace-element concentrations. Photograph by Ralph L. Seiler, U.S. Geological Survey, 1994. 
of selenium exist. In three of those four areas, the rivers supplying water for irrigation traverse Upper Cretaceous or Tertiary marine sedimentary deposits upstream from irrigated areas. Selenium is brought into the Salton Sea area and lower Colorado River valley in California and Arizona ( $U$ and $J$, table 2) in Colorado River water, which traverses Upper Cretaceous marine sedimentary rocks and receives drain water from irrigated agricultural lands hundreds of miles upstream. Selenium is brought also into the lower Rio Grande valley in Texas $(K$, table 2$)$ in Rio Grande water, which traverses Upper Cretaceous and Tertiary marine sedimentary deposits many miles upstream. Although selenium is brought into the Humboldt River area in Nevada ( $G$, table 2), the Humboldt River Basin contains no Upper Cretaceous and Tertiary marine sedimentary deposits.

\section{Classific ation of Study Areas by Selenium Concentrations}

\section{Water}

Water-quality criteria used in this study were based on the U.S. Environmental Protection Agency's (1987) chronic criterion for selenium for the protection of freshwater aquatic life, $5 \mu \mathrm{g} / \mathrm{L}$, and on the avian effect level (Skorupa and Ohlendorf, 1991), $3 \mu \mathrm{g} / \mathrm{L}$ total recoverable selenium. Skorupa and Ohlendorf (1991) found that, under some environmental conditions, a range of 3 to $20 \mu \mathrm{g} / \mathrm{L}$ total recoverable selenium is hazardous to some species of aquatic birds. The NIWQP investigations typically measured filtered selenium, not total recoverable selenium, in water samples. Seiler (1996) presented evidence that in NIWQP samples, filtered- and total-selenium concentrations are nearly the same over a wide range of concentrations; however, whether the analyses are interchangeable is still a matter of debate.

To summarize selenium data, only filtered-selenium concentrations in water from surface-water sites in and downstream from irrigated land were used. Selenium concentrations in ground water, in surface water used for irrigation, and in sediment were not used for this analysis. For simplicity, data for flowing and impounded bodies of water were combined, because no samples or very few samples were collected from lakes and ponds in some areas. Statistics summarizing filtered-selenium concentrations in surface water were generated for the 26 study areas. Summary statistics of data that include censored values (values less than the analytical detection limit) were estimated by probabilityplotting methods (Helsel and Hirsch, 1992) or from lognormal maximum-likelihood distributions (Helsel and Cohn, 1988).
The 75th percentile of the selenium concentrations of water samples from a given area was chosen for comparison with criteria in deciding whether the water in the area was contaminated. (The 75th percentile is the concentration that is exceeded by 25 percent of the samples from the area.) The median was not used because many of the NIWQP investigators collected only a limited number of samples from a large area; a study area would have to be extremely contaminated for half of the samples to exceed water-quality criteria. Areas were classified as contaminated if 25 percent or more of the samples exceeded the U.S. Environmental Protection Agency (USEPA) chronic criterion because, at that high a percentage, fish and aquatic birds probably are exposed to contaminated water.

On the basis of selenium concentrations in surface water (table 2), 12 of the 26 NIWQP areas were classified as selenium contaminated ( $C, E, F, H, M, N, R, S, U, X, Y$, and $Z$ ), 2 were classified as seleniferous ( $B$ and $V$ ), and the remaining 12 were classified as uncontaminated. In the 12 contaminated areas, the filtered-selenium concentrations in 25 percent or more of the surface-water samples equaled or exceeded $5 \mu \mathrm{g} / \mathrm{L}$, the USEPA chronic criterion for selenium for the protection of freshwater aquatic life (table 2, figs. 4 and 5). In the two seleniferous areas, the selenium concentrations in 25 percent or more of the surface-water samples were equal to or greater than the avian effect level, $3 \mu \mathrm{g} / \mathrm{L}$, but less than the USEPA chronic criterion, $5 \mu \mathrm{g} / \mathrm{L}$. In 7 of the 12 uncontaminated areas $(D, I, L, O, P, T$, and $W)$, selenium concentrations in 75 percent or more of the surface-water samples were less than the analytical reporting limit (1 $\mu \mathrm{g} / \mathrm{L})$; in 3 of these 7 areas $(I, L$, and $P$ ), selenium was not detected in any surface-water sample. In the 5 other uncontaminated areas $(A, G, J, K$, and $Q)$, the 75th percentile of selenium concentrations was 1 to $2 \mu \mathrm{g} / \mathrm{L}$.

\section{Biota}

Selenium is a potent teratogen that can induce deformities of embryos and larvae and cause reproductive failure in fish and wildlife without otherwise affecting adults (Lemly, 1993). It is the only inorganic constituent in irrigation drain water that is commonly found in eggs of aquatic birds at concentrations sufficient to cause the death or deformity of an embryo (Skorupa and Ohlendorf, 1991; Ohlendorf and others, 1993). Because of the sensitivity of avian embryos to selenium, avian eggs were collected and analyzed for selenium content in 24 of the 26 NIWQP areas.

Selenium concentrations in avian eggs from the 26 NIWQP study areas were evaluated by grouping the data into sets based on distinct species-site-year permutations. 
NUMBER OF ANALYSES

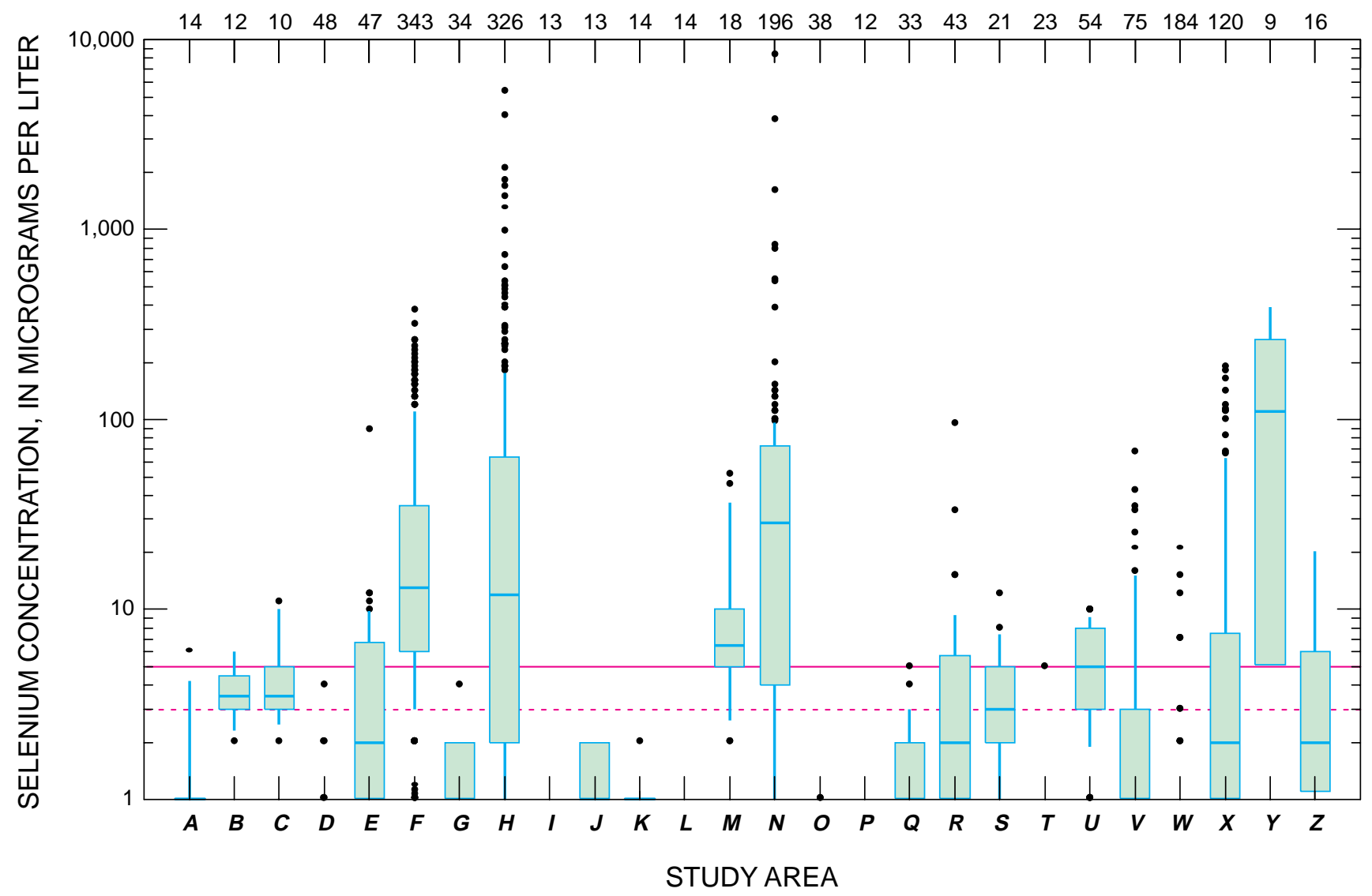

\section{EXPLANATION}

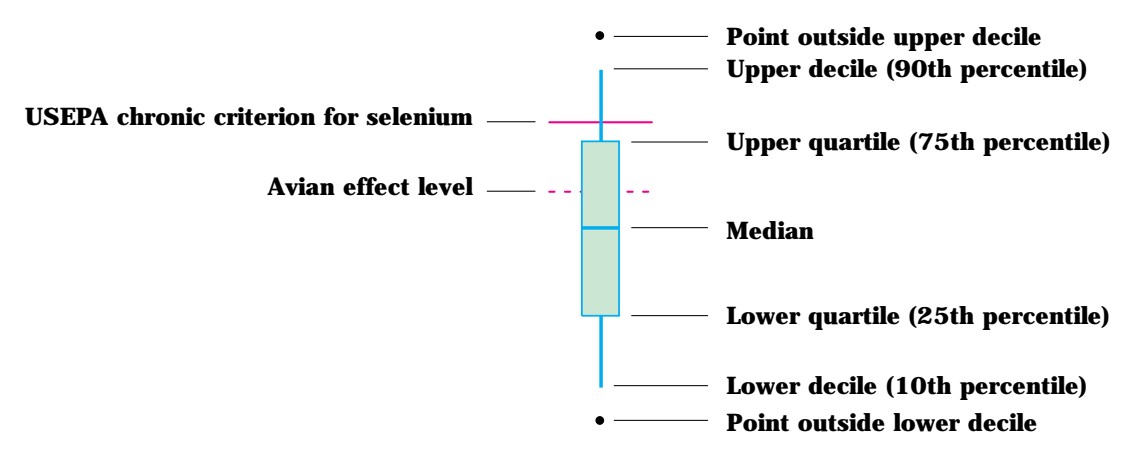

Figure 4. Statistical summary of selenium concentrations in filtered surface water from 26 National Irrigation Water Quality Program study areas (table 2). Chronic criterion from U.S. Environmental Protection Agency (1987) and avian effect level from Skorupa and Ohlendorf (1991). USEPA, U.S. Environmental Protection Agency. 
Each set of eggs conceptually represents a distinct breeding population of birds. For example, the 16 American avocet eggs that were collected from Rasmus Lee Lake, Wyo., in 1988 represent a set; the 86 American avocet eggs that were collected at the same site in 1989 represent another set. In some instances, a single egg or a composite sample of two or more eggs represents the set for a particular breeding population of birds.

The geometric mean of the selenium concentrations of all the eggs in each set was calculated and is referred to in this report as the selenium concentration of the egg set. Ohlendorf (1989) reported that selenium concentrations of egg sets from uncontaminated areas averaged about 1 to 3 $\mu \mathrm{g} / \mathrm{g}$ selenium dry weight. Skorupa and Ohlendorf (1991) reported that egg sets having selenium concentrations greater than about $8 \mu \mathrm{g} / \mathrm{g}$ dry weight are associated with significantly reduced hatchability. Data from field sampling suggest that a threshold for teratogenesis occurs within the range from 13 to $24 \mu \mathrm{g} / \mathrm{g}$. A population-level threshold is the lowest mean concentration of selenium in a set of eggs that is expected to consistently identify populations in which one or more hens are producing embryos with selenium-induced deformities. Population-level egg criteria are not appropriate for individual-level risk assessment because they do not identify individuals at risk.

The 26 NIWQP study areas were classified into three groups on the basis of the maximum mean selenium concentration of representative egg sets (table 2): normal (less than or equal to $3 \mu \mathrm{g} / \mathrm{g}$ ), elevated (greater than $3 \mu \mathrm{g} / \mathrm{g}$ but less than $8 \mu \mathrm{g} / \mathrm{g}$ ), and embryotoxic (equal to or greater than $8 \mu \mathrm{g} / \mathrm{g}$ ). Further work since that of Skorupa and Ohlendorf's (1991) has indicated that the safe exposure level for some species of birds is less than $8 \mu \mathrm{g} / \mathrm{g}$. For instance, for black-necked stilt embryos, Skorupa (1998) concluded that $6 \mu \mathrm{g} / \mathrm{g}$ represents the upper boundary of safe exposure, which is only two to three times the normal background level. Thus, the threshold for toxic effects used in this report, $8 \mu \mathrm{g} / \mathrm{g}$, is conservative.

Multiple overt deformities similar to those found in bird embryos at Kesterson National Wildlife Refuge were found in bird embryos in 4 of the 26 areas $(F, H, N$, and $Y$, table 2). Deformed birds were found in other areas, but selenium toxicosis was not confirmed; instead, the deformities may represent the normal background rate of deformities that would occur in any bird population.

\section{Use of a Geographic Information System to Create Maps}

GIS data layers (sets of spatially located digital data) showing land use, mean annual precipitation, FWSE, and geology of the United States were obtained or created to use for data analysis in this report (table 4). Each piece of data has an associated set of $\mathrm{x}$ and $\mathrm{y}$ coordinates (for example, latitude and longitude) that are used to locate the data spatially.

Many of the data layers used in this investigation are available through the NIWQP World Wide Web site, which can be located by using a search engine to find the acronym "NIWQP."

\section{Geologic Data Layers}

A GIS data layer of the geology of the United States derived from the King and Beikman (1974a) geologic map was released on CD-ROM by Schruben and others (1994). The CD-ROM may be purchased from the USGS Earth Science Information Center (telephone 1-800-USA-MAPS or 1-800-872-6277 or 1-888-275-8747). It may be obtained also through the USGS World Wide Web site at

\section{http://mapping.usgs.gov/esic/cdrom}

Geologic-map units from the King and Beikman (1974a) map (table 3) were grouped together to create a GIS data layer of Upper Cretaceous marine sedimentary rocks, Tertiary marine sedimentary deposits, and Tertiary continental sedimentary deposits. The following King and Beikman (1974a) map units of Upper Cretaceous, mainly marine, stratified sedimentary sequences were combined: $\mathrm{uK}^{\mathrm{K}} \mathrm{uK}_{1}$, $u K_{2}, u K_{3}, u K_{3} a, u K_{3} b$, and $u K_{4}$. As compiled in this report, these are called Upper Cretaceous marine sedimentary rocks. The following map units of Tertiary (Paleocene to Pliocene), mainly marine, stratified sedimentary sequences were combined: $\mathrm{Tx}, \mathrm{Te}, \mathrm{Te}_{1}, \mathrm{Te}_{2}, \mathrm{Te}_{3}, \mathrm{To}, \mathrm{Tm}$, and $\mathrm{Tp}$. As compiled in this report, these are called Tertiary marine sedimentary deposits. The following Paleocene to Pliocene continental sedimentary deposits were grouped together: Txc, Tel, Tec, Toc, Tmc, and Tpc. As compiled in this report, these deposits are called Tertiary continental sedimentary deposits. 
TABLE 4. Geographic-information-system data layers used to create maps in this report

\begin{tabular}{|c|c|c|c|c|}
\hline \multirow{2}{*}{ Data type } & \multicolumn{2}{|c|}{ GIS data layer } & \multirow{2}{*}{$\begin{array}{c}\text { Data sources } \\
\text { (bold indicates direct source of } \\
\text { published data used in GIS data layer) }\end{array}$} & \multirow{2}{*}{$\begin{array}{c}\text { Scale of } \\
\text { published map }\end{array}$} \\
\hline & Name of data layer & Year created & & \\
\hline \multicolumn{5}{|c|}{ Geologic } \\
\hline Bedrock geology & KBGE & 1994 & $\begin{array}{l}\text { Schruben and others (1994) } \\
\text { King and Beikman (1974a) }\end{array}$ & $\begin{array}{l}1: 2,500,000 \\
1: 2,500,000\end{array}$ \\
\hline \multicolumn{5}{|c|}{ Climatologic } \\
\hline Evaporation (FWSE) & FWSE $^{1}$ & 1996 & Farnsworth and others (1982) & $1: 5,000,000$ \\
\hline Precipitation (NOAA) & NORMPRE $^{1}$ & 1994 & $\begin{array}{l}\text { Rea and Cederstrand (1994) } \\
\text { Owenby and others (1992) }\end{array}$ & $1: 5,000,000$ \\
\hline Precipitation (PRISM) & US_9310 2 & 1994 & Daly and others (1994) & - \\
\hline \multicolumn{5}{|c|}{ Land use } \\
\hline BOR project areas & BORAREAS $^{1}$ & 1995 & Bureau of Reclamation (1988) & $\sim 1: 5,850,000$ \\
\hline Irrigated agricultural land & IRRAG $^{1}$ & 1996 & $\begin{array}{l}\text { Earth Resources Observation System } \\
\text { Data Center (1990). }\end{array}$ & $1: 7,500,000$ \\
\hline National Wildlife Refuges & NWRAREAS $^{1}$ & 1995 & U.S. Fish and Wildlife Service (1988) & $1: 3,000,000$ \\
\hline \multicolumn{5}{|c|}{ Interpretive } \\
\hline Evaporation index & $\mathrm{EI}^{1}$ & 1994 & Derived from climatologic data layers & ${ }^{3} 1: 19,700,000$ \\
\hline Susceptible areas & $\begin{array}{l}\text { SUSCEP } 25^{1} \text {, } \\
\text { SUSCEP } 30^{1} \text {, } \\
{\text { SUSCEP } 35^{1} \text {, and }} \\
\text { SUSCEP50 }^{1} \text {. }\end{array}$ & 1994 & $\begin{array}{l}\text { Derived from climatologic and geologic } \\
\text { data layers. }\end{array}$ & ${ }^{2} 1: 19,700,000$ \\
\hline
\end{tabular}

\footnotetext{
${ }^{1}$ These digital data are documented in accordance with USGS policy (Nebert, 1994) and are on file in USGS office in Carson City, Nev.

${ }^{2}$ Version of PRISM used for this study report was obtained from G.H. Taylor, Oregon State Climatologist, October 1993.

${ }^{3}$ Published in this report.
}

\section{Climatologic Data Layers}

Two GIS data layers of mean annual precipitation in the United States were obtained and compared. The first data layer was digitized from Owenby and others' (1992) map of normal mean annual precipitation for the years 1961 to 1990. The other data layer was derived from Daly and others' (1994) "precipitation-elevation regressions on independent slopes model" (PRISM), a proprietary data layer available from George H. Taylor, Oregon State Climatologist (e-mail, oregon@oce.orst.edu; URL, http://www.ocs.orst.edu). The PRISM data layer was used because its resolution is much finer than the first data layer and its contour intervals are smaller. A GIS data layer of FWSE rates (table 4) was created from Farnsworth and others' (1982) FWSE map.
The FWSE and PRISM data layers were converted into gridded surfaces by interpolating between the isograms for precipitation and evaporation. The gridded surface overestimates annual precipitation for large areas of California, Arizona, and Nevada because the minimum isogram on the precipitation map is 10 inches. In these areas, annual precipitation is interpolated uniformly as 10 inches.

The EI data layer was created by dividing evaporation values by corresponding precipitation values. The resulting surface was contoured according to the following EI intervals: 0 to 2.5 , greater than 2.5 to 3.5 , greater than 3.5 to 5.0 , and greater than 5.0. 


\section{Land-Use Data Layers}

Data layers and maps showing the locations of Bureau of Reclamation project areas and National Wildlife Refuges were derived by digitizing maps prepared by the Bureau of Reclamation (1988) and the U.S. Fish and Wildlife Service (1988). The map by the Bureau of Reclamation (1988) shows the areal extent of most of their project areas; the few project areas that are shown only as points on this map were plotted on the USGS data layer BORAREAS (table 4) as rectangular polygons sized according to the actual project areas, as reported by the Bureau of Reclamation (1981).

Few designated wildlife areas are shown on nationalscale maps; the U.S. Fish and Wildlife Service (1988) map shows point locations of only those National Wildlife Refuges that have visitor centers. Therefore the derived land-use data layer does not include State and local refuges or wildlife-management areas and also excludes National Wildlife Refuges that do not have visitor centers.

A GIS data layer showing the distribution of irrigated agricultural land in the Western United States was derived from Earth Resources Observation System Data Center (1990) satellite images showing seasonal land-cover regions. The data layer, which was derived from Advanced Very High Resolution Radiometer data (commonly called AVHRR data) by grouping those areas where croplands were coded as "irrigated agriculture," has a resolution of 1 square kilometer (about 0.4 square mile).

\section{FACTORS AFFCTING SEIENIUM CONCENTRATIONS IN WATER}

Numerous investigators have identified features common to selenium-contaminated lands. Analysis of data from the NIWQP data set confirms previous investigators' conclusions and expands upon their work to produce regional-scale maps identifying areas in the Western United States susceptible to irrigation-induced selenium contamination. The relations among geology, selenium concentration in water, and EI (aridity) are shown in figure 5.

\section{Geology}

The importance of Upper Cretaceous marine sedimentary rocks as sources of selenium is apparent in the NIWQP data set. In 8 of the 26 areas, the bedrock is mainly Upper Cretaceous marine sedimentary rock, and in 4 of the 26 areas, it is Upper Cretaceous marine and Tertiary continental sedimentary rock (figs. $5 A, B$; table 2 ). In 11 of these 12 areas, more than 25 percent of the surface-water samples contain selenium concentrations equal to or exceeding the avian effect level, $3 \mu \mathrm{g} / \mathrm{L}$. Upper Cretaceous marine sedimentary rocks are upland from 3 of the 26 study areas (fig. $5 C$, table 2$)$ and in 2 of those areas ( $S$ and $Y$, table 2) more than 25 percent of the surface-water samples contain selenium concentrations equal to or exceeding $5 \mu \mathrm{g} / \mathrm{L}$ (fig. $5 \mathrm{C}$ ).

The importance of Tertiary marine sedimentary deposits as sources of selenium is difficult to assess by using the NIWQP data set. Only two NIWQP study areas ( $K$ and $Y$, tables 2 and 3 ) are associated with Tertiary marine sedimentary deposits. In the lower Rio Grande valley in Texas $(K)$, which is uncontaminated, one background site is on Eocene marine sedimentary deposits and the remainder of the datacollection sites are on Holocene sedimentary deposits. In the Tulare Lake Bed area in California $(Y)$, which is contaminated, all the sites are associated with Quaternary sedimentary deposits. Although the principal sources of selenium in the area are probably Tertiary marine sedimentary deposits, Upper Cretaceous marine sedimentary rocks also may be sources. Fujii and Swain (1995, pl. 1) showed that Tertiary marine sedimentary deposits are within a few miles upland from the Tulare Lake Bed area and that pre-Tertiary (including Cretaceous) marine sedimentary rocks are about 15 to 20 miles upland. Presser (1994a) stated that the Miocene Monterey Formation, which consists of marine sedimentary rocks and is upland from the Tulare Lake Bed area, is seleniferous and is a suspected source of selenium found in the area. Selenium concentrations in 22 rock samples from the Monterey Formation ranged from less than 3 to $56 \mathrm{mg} / \mathrm{kg}$; the median concentration was $10.5 \mathrm{mg} / \mathrm{kg}$, and the mean was $15.5 \mathrm{mg} / \mathrm{kg}$ (Piper and Isaacs, 1995). For comparison, selenium concentrations in 527 rock samples from the marine Niobrara and Pierre Formations of Cretaceous age in South Dakota ranged from 0 to $113 \mathrm{mg} / \mathrm{kg}$, and the mean was 5.8 $\mathrm{mg} / \mathrm{kg}$ (Moxon and others, 1939).

Similarly, the importance of Tertiary continental sedimentary deposits as sources of selenium is difficult to assess by using the NIWQP data set. In 4 of the 26 study areas ( $N$, $R$, $S$, and $V$, table 2), lower Tertiary (Paleocene-Eocene) continental sedimentary rocks form some or all bedrock, and in 3 of the 26 areas $(M, O$, and $Q$, table 2$)$, upper Tertiary (Pliocene) continental sedimentary rocks form some of the bedrock (table 3). Selenium contamination occurs in four of these seven areas $(M, N, R$, and $S)$, and one is classified as seleniferous $(V)$. Two of the areas are uncontaminated $(O$ and $Q)$ and contain Pliocene continental sedimentary deposits, but no Upper Cretaceous marine sedimentary rocks are in or near the areas. In four of the five contaminated or seleniferous areas $(M, N, R$, and $V)$, Upper Cretaceous marine sedimentary rocks form some of the bedrock, and in the fifth (S), the mountains upland from irrigated lands include Upper Cretaceous marine sedimentary rocks. 

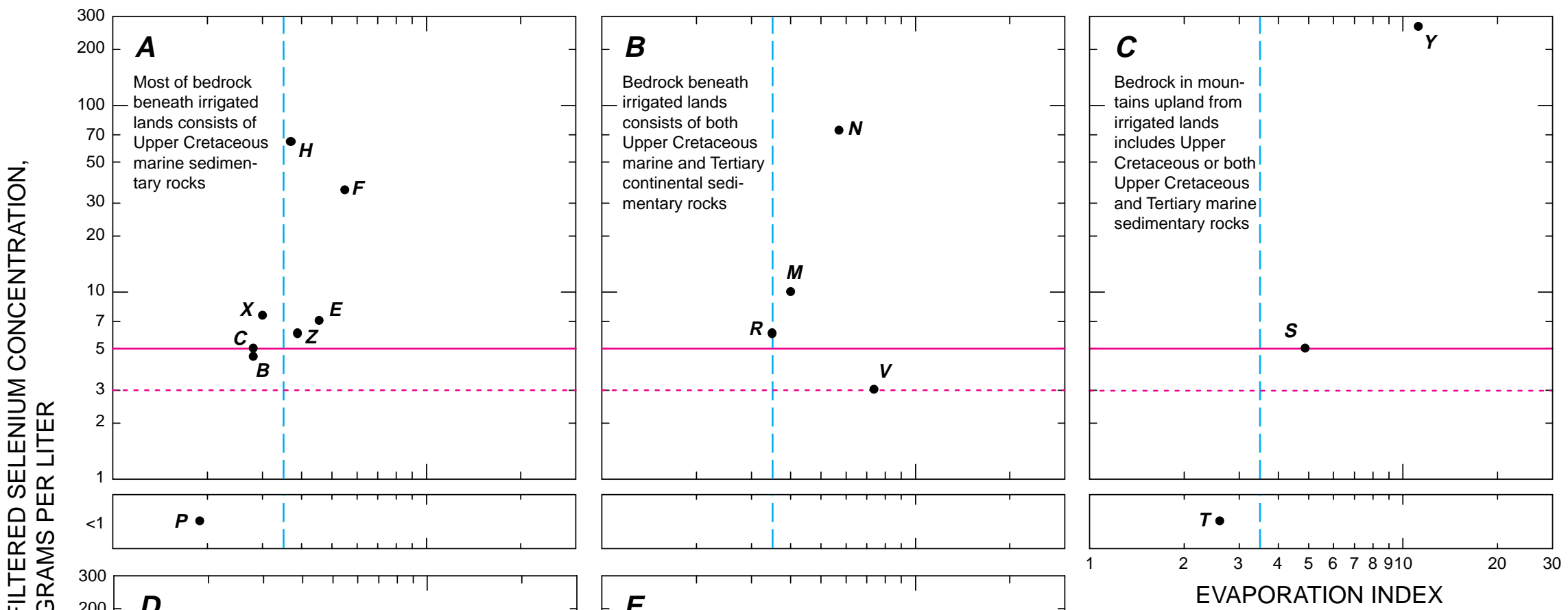

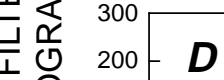

山

足 100 - irrigation traverse Upper

$\sum \sum$ Cretaceous or both Upper

\section{$E$}

No association with Upper

Cretaceous marine

sedimentary rocks

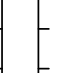

$\boldsymbol{J} \bullet$

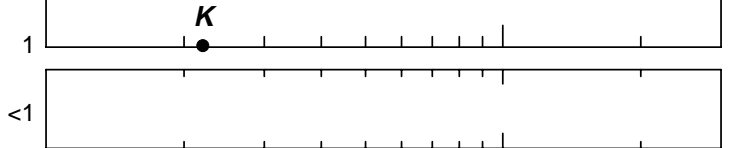

$20 \quad 30$

301

EVAPORATION INDEX

\section{EXPLANATION}

U.S. Environmental Protection Agency chronic criterion for selenium

\section{Avian effect level}

Evaporation index above which corresponding selenium concentrations typically exceed U.S. Environmental Protection Agency chronic criterion for selenium

\section{- A National Irrigation Water Quality Program} data—Letter indicates study area

Figure 5. Relations among selenium concentration, evaporation index (aridity), and geology for 26 National Irrigation Water Quality Program study areas (table 2). Chronic criterion for selenium is from U.S. Environmental Protection Agency (1987), and avian effect level, from Skorupa and Ohlendorf (1991). 
The best evidence of the importance of rocks and sedimentary deposits of Tertiary age in the NIWQP data set is in the Ouray subarea of the middle Green River Basin, Utah $(N$, table 3). Ground-water samples from this subarea commonly contain selenium in concentrations exceeding $100 \mu \mathrm{g} / \mathrm{L}$; the maximum measured value is $9,300 \mu \mathrm{g} / \mathrm{L}$ (Stephens and others, 1992, p. 89). Ponds used by wildlife in the subarea commonly contain selenium at concentrations exceeding $20 \mu \mathrm{g} / \mathrm{L}$, and deformed bird embryos have been found at these ponds. All the data-collection sites in the Ouray subarea are associated with Eocene continental sedimentary deposits (table 3), and the nearest exposure of Upper Cretaceous marine sedimentary rock is about 14 miles upstream. Trelease and Beath (1949, p. 80) noted that seleniferous plants occur in parts of the Eocene Uinta Formation, which is exposed in the area (Stephens and others, 1992).

Knowing where selenium contamination does not occur is nearly as important as knowing where it does occur. In the Western United States, areas are unlikely to be contaminated by selenium if they do not contain and have no nearby Upper Cretaceous or Tertiary marine sedimentary deposits. Of the 26 areas, 11 fit this description $(A, D, I, G, J, K, L, O, Q, U$, and $W$, figs. $5 D, E$; tables 2 and 3 ). Only 2 of these 11 areas ( $J$ and $U$ ) have selenium problems; selenium is brought into both areas in water imported for irrigation. The Salton Sea $(U)$ is considered to be contaminated on the basis of the concentration of water-borne selenium (table 2), and bird eggs from the Lower Colorado River valley area $(J)$ contain embryotoxic concentrations of selenium (William G. Kepner, U.S. Fish and Wildlife Service, written commun., 1989). The selenium concentration at the 75 th percentile in the remaining 9 areas is less than $3 \mu \mathrm{g} / \mathrm{L}$; in 5 of these 9 areas, it is less than the analytical reporting limit $(1 \mu \mathrm{g} / \mathrm{L})$.

\section{Climate}

In areas that do not have local geologic sources of selenium such as Upper Cretaceous marine sedimentary rocks (fig. 5E), selenium concentrations do not increase as aridity increases. In areas that do have a local geologic source of selenium (figs. $5 A, B$ ), concentrations generally increase as aridity increases.

Areas having very low evaporation indices are unlikely to have selenium-contamination problems even if Upper Cretaceous marine sedimentary rock (fig. 5A) or some other source of selenium is nearby. This is supported by data from the Milk River Basin, Mont. ( $P$, fig. 1, table 2), where seleniferous sedimentary deposits are dominant. Data were collected in the Milk River Basin during a year in which flooding occurred and sufficient water was available to dilute the contaminants; no selenium was detected in any of the NIWQP surface-water samples. EI calculated for the flood year was 1.9, which was the lowest of any for the 26 areas. Data collected under more normal conditions indicate that the area is contaminated when precipitation is less abundant. Presser and others (1994) reported that elevated concentrations of selenium had been measured in a stream in the area. Lambing and others (1988) reported that selenium concentrations in Lake Bowdoin were $6 \mu \mathrm{g} / \mathrm{L}$ in 1985 and less than $1 \mu \mathrm{g} / \mathrm{L}$ in 1986 , when the NIWQP samples were collected.

The distribution of areas in the Western United States where EI exceeds 2.5 is shown in figure 6; total areas of land where EI exceeds four threshold values are given in table 5. An EI value of 2.5 is considered important because it is between the lowest EI value for an uncontaminated area (1.9 for area $P$, fig. $5 A$ ) and the lowest EI value for a seleniumcontaminated area (2.8 for area $C$, fig. $5 A$ ). An EI value of 3.5 is considered important because the 75 th percentile of the selenium concentrations typically exceeds the USEPA chronic criterion for selenium $(5 \mu \mathrm{g} / \mathrm{L})$ if EI exceeds 3.5 (figs. $5 A, B$ ). In almost one third of the land area in the Western United States, EI is 3.5 or greater and selenium contamination resulting from irrigation of an area is likely if geologic sources of selenium are in or near the area.

\section{Hydrology}

Selenium brought into an area can cause contamination in areas without local geologic sources of selenium. The discharge of irrigation drain water, oil-field brines, coal fly ash, or mine-dewatering effluent that contains selenium into a stream can result in contamination in areas hundreds of miles downstream. An example is the contaminated Salton Sea area ( $U$, figs. 1 and $5 D$ ) in the Imperial Valley in California. This area is contaminated mainly because selenium is brought into the area in Colorado River water (Setmire and others, 1993), although Tertiary marine sedimentary bedrock exposed in small areas in the mountains to the west may contribute some selenium to the area.

Areas that have terminal lakes or ponds and sources of selenium within the drainage basin are especially at risk for becoming contaminated. Evaporative enrichment can cause elevated selenium concentrations in terminal water bodies. Also, because the selenium is not flushed out during normal spring runoff, selenium concentrations can increase because selenium from several seasons remains in the water. 


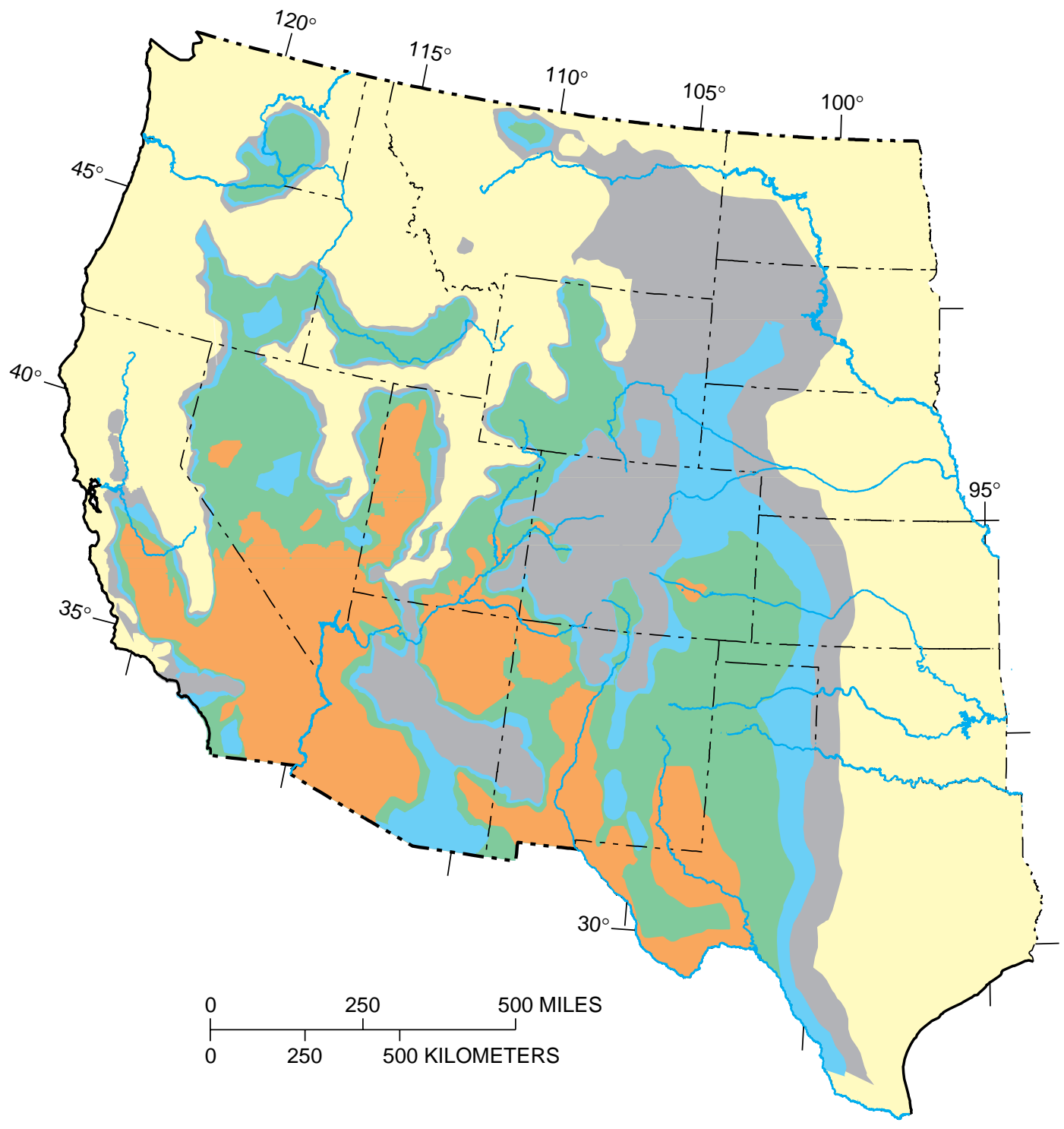

EXPLANATION

\section{Evaporation index:}

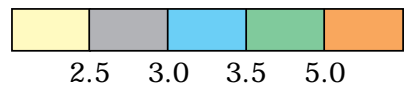

Figure 6. Evaporation index in Western United States. Climate data from Farnsworth and others (1982) and G.H. Taylor (Oregon State Climatologist, written commun., 1994). For base credit, see figure 1. 
TABLE 5. Western United States land areas where evaporation indexes exceed four threshold values

\begin{tabular}{ccc}
\hline $\begin{array}{c}\text { Evaporation } \\
\text { index }\end{array}$ & $\begin{array}{c}\text { Land area in } \\
\text { Western } \\
\text { United States } \\
\text { (square miles) }\end{array}$ & $\begin{array}{c}\text { Percentage } \\
\text { of total area } \\
\text { of Western } \\
\text { United States }\end{array}$ \\
\hline Greater than 2.5 & $1,024,000$ & 56 \\
Greater than 3.0 & 709,000 & 38 \\
Greater than 3.5 & 566,000 & 31 \\
Greater than 5.0 & 237,000 & 13 \\
\hline
\end{tabular}

\section{DEFORMIIES IN AQUATIC BIRDS AND SELENIUM CONCENIRATIONS IN BIRD EGGS}

Selenium poisoning causes multiple overt deformities in bird embryos (fig. 7); these deformities typically include hydrocephaly, missing eyes, twisted bills, and deformed limbs (Hoffman and Heinz, 1988; Hoffman and others, 1988). Bird embryos with multiple overt deformities, like those in birds from Kesterson Reservoir, were found in 4 of the 26 NIWQP areas ( $F, H, N$, and $Y$, table 2). In those four areas, the median selenium concentrations in surface water exceeded $10 \mu \mathrm{g} / \mathrm{L}$ (fig. 4), which is twice the USEPA chronic criterion for the protection of freshwater aquatic life.

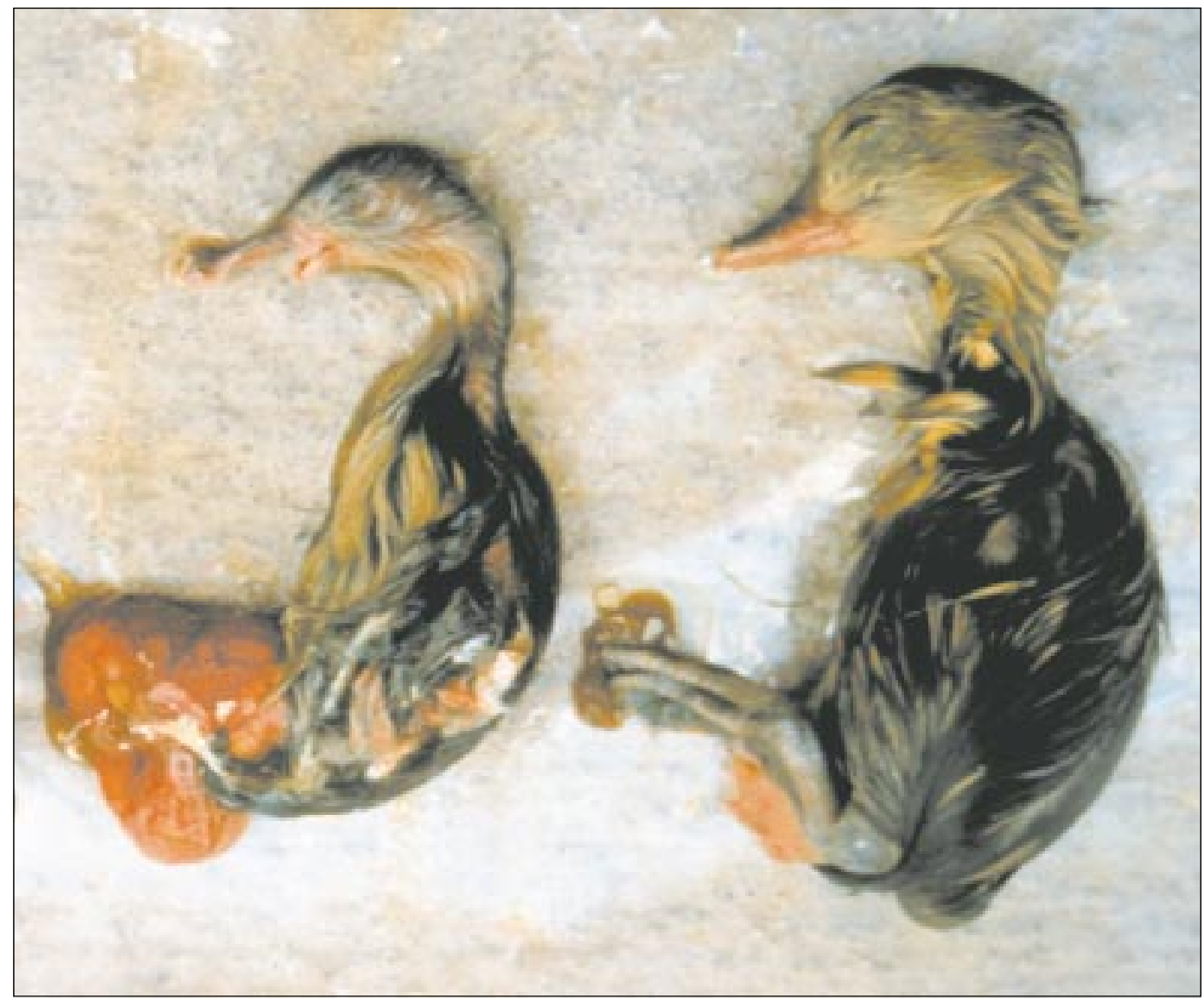

Figure 7. Redhead duck embryos from middle Green River Basin study area in Utah. Left embryo shows twisted bill and other deformities typical of those caused by selenium; right embryo is normal. Photograph by Bruce Waddell, U.S. Fish and Wildlife Service, 1989. 
Deformed birds were found in four other areas $(U, V, W$, and $X)$, but the cause of the deformities could not clearly be attributed to selenium. In at least some of these instances, the types and numbers of deformities found may represent the normal background rate found in any natural avian population.

Bird eggs from 24 of the 26 areas were sampled and analyzed for selenium. Of the areas sampled, 12 were classified as embryotoxic ( $C, E, F, H, J, N, R, S, V, W, X$, and $Y$, table 2) because the selenium concentration in at least 1 of the egg sets exceeded levels associated with significantly reduced hatchability; 6 areas were classified as normal $(A, B$, $I, L, O$, and $P$ ) because the selenium concentrations of all the egg sets were within the normal range; and the 6 remaining areas were classified as elevated $(D, G, M, Q, I$, and $U$ ) because the selenium concentration in at least 1 of the egg sets was above the normal range.

\section{MAP IDENTIFYING AREAS SUSCEPTIBIE TO SEIENIUM CONTAMINATION}

Although many Federal, State, and local irrigationproject areas in the Western United States may be susceptible to irrigation-induced selenium contamination, limited financial and human resources preclude comprehensive investigations of all irrigated land. Cost-effective tools to identify areas where irrigation is likely to cause selenium contamination make it possible to target resources effectively toward investigating those areas at highest risk.

The NIWQP data indicate that irrigation is likely to result in selenium contamination if geologic sources of selenium are in or near the area and if EI is greater than about 2.5. A map showing areas having this combination of geologic and climatic characteristics was created by intersecting the GIS geology data layers of Upper Cretaceous and Tertiary marine sedimentary deposits (fig. 2) and the EI data layer (fig. 6). The resulting map identified about 160,000 square miles of land in the Western United States that is considered to be susceptible to irrigation-induced selenium contamination (table 6, fig. 8). About 52,600 square miles of land in the Western United States is considered to be even more susceptible because EI exceeds 3.5.

Land adjacent to areas mapped as susceptible to contamination (fig. 8) also should be treated provisionally as susceptible because selenium can be transported from source areas in mountains to irrigated areas in adjacent valleys. In
California, all the areas mapped as susceptible are in mountain ranges where there is no irrigation. Although not indicated on the map, the actual susceptible areas are the irrigated alluvial fans and valleys at the base of the mountains. Another reason to consider land adjacent to areas mapped as susceptible is that the parent material for the soils may be seleniferous Tertiary continental sedimentary deposits. The NIWQP data clearly indicate that selenium contamination can develop in areas of Tertiary continental sedimentary rocks if Upper Cretaceous marine sedimentary rocks are nearby.

\section{Assessing Map Reliability}

\section{TestAreas}

The map correctly classified 22 of the 26 NIWQP study areas (fig. 9, table 7). Of the 14 areas classified as seleniferous or contaminated, 12 were identified correctly by the map because they are on or adjacent to areas mapped as susceptible. One of the two areas not so identified was the Salton Sea area $(U$, table 7$)$, which could not be identified by the criteria used to construct the map because selenium is brought into the Imperial Valley in the water imported for irrigation.

The second contaminated NIWQP area that was not identified from the map is the Sun River area $(X$, table 7$)$ in central Montana. This area is mapped as not susceptible although it is known to be selenium contaminated. The reason it was not identified is insufficient resolution of climatological data (see section "Accuracy and Precision of Maps").

TABLE 6. Western United States land areas where evaporation indexes exceed four threshold values and where bedrock consists of Upper Cretaceous or Tertiary marine sedimentary rocks

\begin{tabular}{ccc}
\hline & $\begin{array}{c}\text { Land where Upper Cretaceous or Tertiary marine } \\
\text { sedimentary rocks form bedrock }\end{array}$ \\
\cline { 2 - 3 } Evaporation index & $\begin{array}{c}\text { Area } \\
\text { (square miles) }\end{array}$ & $\begin{array}{c}\text { Percentage of total } \\
\text { Western United States }\end{array}$ \\
\hline Greater than 2.5 & 160,000 & 8.7 \\
Greater than 3.0 & 83,300 & 4.5 \\
Greater than 3.5 & 52,600 & .9 \\
Greater than 5.0 & 17,300 & 2.9 \\
\hline
\end{tabular}




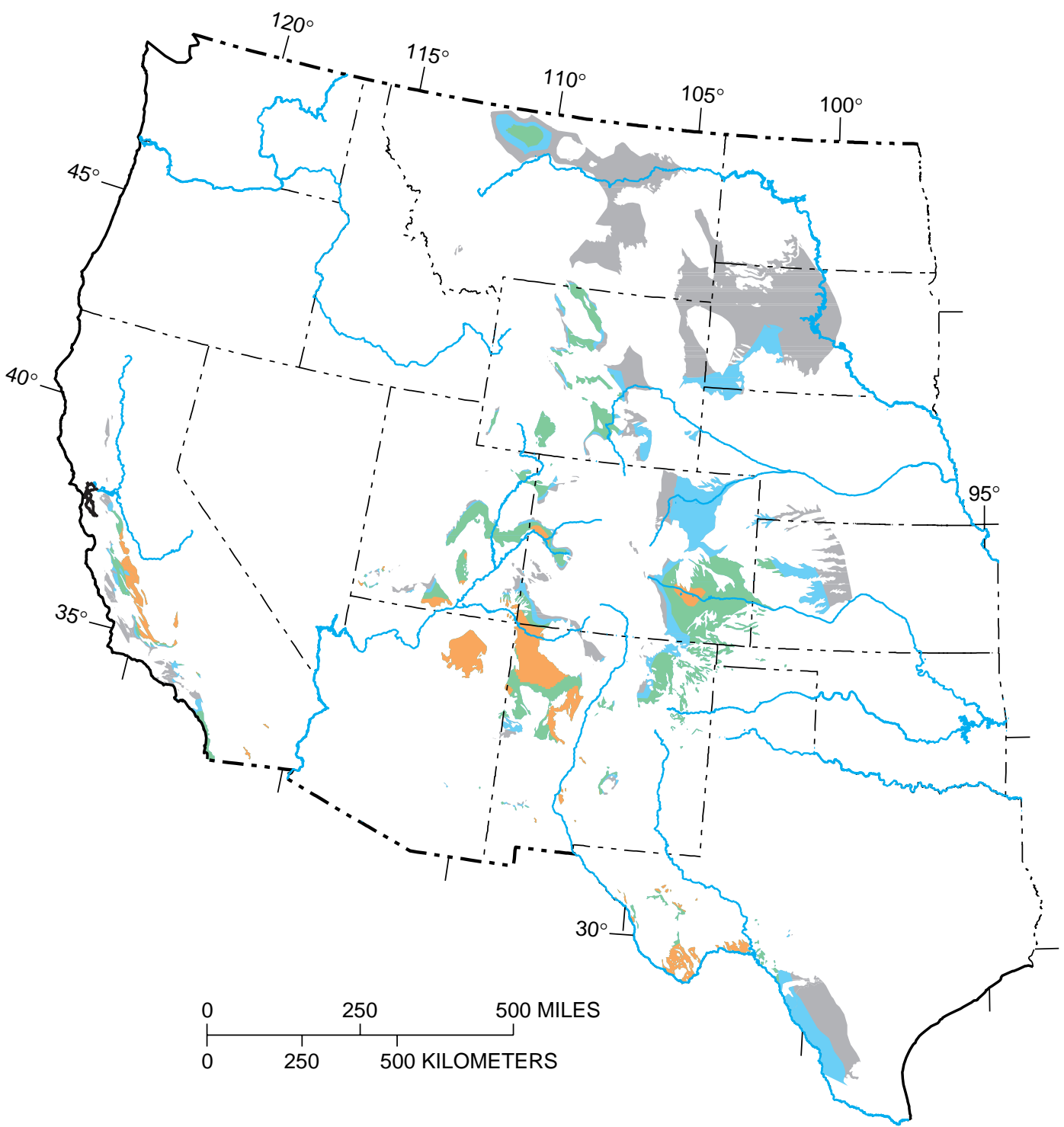

\section{EXPLANATION}

Evaporation index in areas where geologic units are mainly Upper Cretaceous or Tertiary marine sedimentary deposits:

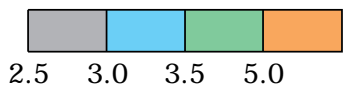

Figure 8. Areas in Western United States that are identified as susceptible to irrigation-induced selenium contamination on basis of Upper Cretaceous or Tertiary marine sedimentary bedrock (fig. 2) and evaporation-index values greater than 2.5 (fig. 6). For base credit, see figure 1. 
Reconnaissance investigations did not identify selenium problems in two NIWQP areas shown on the map as being at risk for selenium contamination. The first area is the Sacramento Refuge Complex in California ( $T$, table 7 ). Although this area is adjacent to an area mapped as susceptible, it has one of the lowest EI values (2.6) of the NIWQP areas. Therefore, being near seleniferous rocks may not result in contamination if EI is low. The second area is the Milk River Basin, Mont. ( $P$, table 7). All the selenium concentrations in surface water measured there were less than 1 $\mu \mathrm{g} / \mathrm{L}$. As discussed in the section "Climate" under "Factors Affecting Selenium Concentrations in Water," all samples from the Milk River Basin were collected during a year in which flooding occurred; however, data from Lambing and others (1988) and Presser and others (1994) show that this area is contaminated under more normal circumstances.

Whether selenium-contaminated areas can be identified correctly from the map also was assessed by plotting the locations of areas where selenium investigations have been done as part of programs other than the NIWQP. The classic example of irrigation-induced selenium contamination, Kesterson Reservoir in Merced County, Calif., is adjacent to an area mapped as susceptible (fig. 9). Data from Kesterson Reservoir indicate the importance of provisionally treating areas as susceptible when they are adjacent to areas mapped as susceptible. Selenium in drain water discharged to Kesterson Reservoir originated in the Cretaceous and Tertiary marine sedimentary rocks and deposits in the California coast ranges upland from irrigated soils (Presser, 1994a).

Selenium contamination was discovered recently at Red Rock Ranch (fig. 9), an agroforestry experimental farm south of Kesterson Reservoir. The Red Rock Ranch is next to an area mapped as susceptible. Irrigation drain water at the Red Rock Ranch was reused for irrigation of salt-tolerant plants and ultimately contained extremely high concentrations of selenium; selenium concentrations were $1,200 \mu \mathrm{g} / \mathrm{L}$ in the water used for the last crop (M.A. Martin, Westside Resource Conservation District, oral commun., 1996) and more than $11,000 \mu \mathrm{g} / \mathrm{L}$ in shallow evaporation ponds (California Regional Water Quality Control Board, Central Valley Region, unpub. data, 1996). Black-necked stilts nesting in the area were exposed to the water and more than 60 percent of the eggs sampled contained deformed embryos (B.E. Van Vorts, California Regional Water Quality Control Board, Central Valley Region, written commun., 1996).
In the mid-1980's, the West Oakes area of North Dakota (fig. 9) was investigated for potential selenium problems because of the area's association with Cretaceous sedimentary rocks (Goolsby and others, 1989). The map classified this area as not susceptible because EI for the area is less than 2.5. That classification is supported by data from Goolsby and others (1989). They found a maximum selenium concentration of $4 \mu \mathrm{g} / \mathrm{L}$ in 63 samples from 23 subsurface drains and a maximum of $1.4 \mu \mathrm{g} / \mathrm{L}$ in 137 surface-water samples from 7 sites not far from West Oakes.

The reliability of the map also was assessed by evaluating data from NIWQP investigations that were not analyzed for this study because the data were not available earlier. The Wind River Indian Reservation in Wyoming and the Emery Project and Scofield Project areas in Utah are on and adjacent to land mapped as susceptible to selenium contamination (fig. 9). Data for the Wind River Indian Reservation, collected during 1992-1993 (Grasso and others, 1995), support classification of the area as susceptible. They found that 6 of 14 surface-water samples from the Little Wind Irrigation Unit had selenium concentrations that exceeded $5 \mu \mathrm{g} / \mathrm{L}$ and the maximum concentration was $17 \mu \mathrm{g} / \mathrm{L}$. Stephens and others' (1997) data for the Emery Project and Scofield Project areas, collected during 1994, support classification of the areas as susceptible. They found that 9 of 45 surface-water samples from the areas had selenium concentrations that exceeded $5 \mu \mathrm{g} / \mathrm{L}$ and the maximum concentration was $46 \mu \mathrm{g} / \mathrm{L}$.

The Walker River Indian Reservation in Nevada is not on land mapped as susceptible (fig. 9). Thodal and Tuttle's (1996) data, collected in the area during 1994, support classification of the area as not susceptible. Selenium was not detected in any of 25 surface-water samples from the area.

The biological significance of the map was assessed using selenium concentrations in avian eggs and fish collected by the NIWQP. The map is based on the results of an analysis of geologic, hydrologic, climatic, and water-quality data. Biological data were not used in that analysis and provide an independent test of the map. In 12 of the NIWQP areas, the mean selenium concentration of at least one set of avian eggs was classified as embryotoxic (table 2 and fig. 9). The map identified 9 of those 12 areas as susceptible to irrigation-induced selenium contamination. 


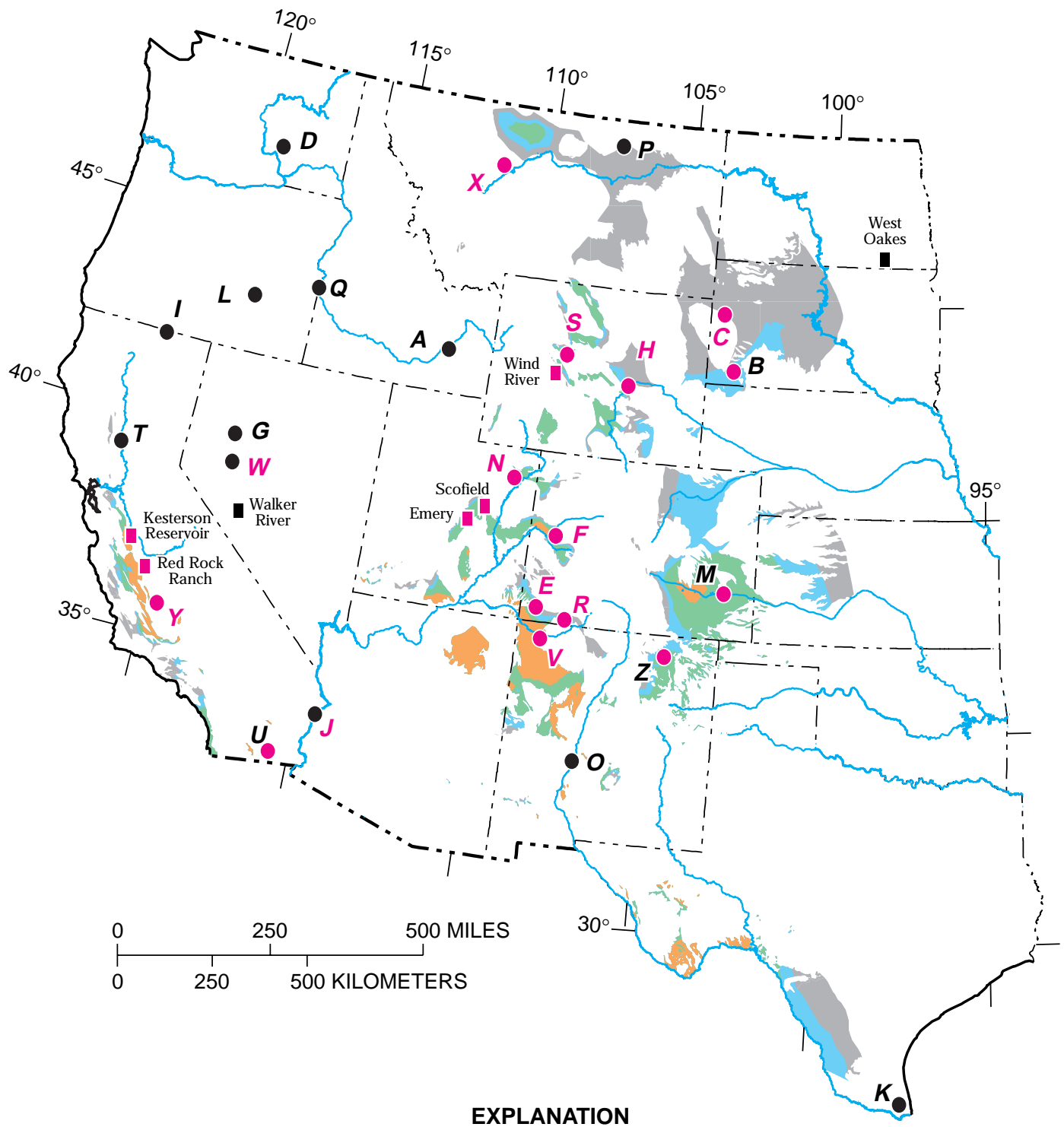

Evaporation index in areas where geologic units are mainly Upper Cretaceous or Tertiary marine sedimentary deposits:

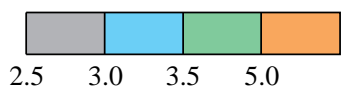

National Irrigation Water Quality Program study areas:

W $\quad$ Area classified as uncontaminated and where some bird eggs contain embryotoxic concentrations of selenium

$Y \quad$ A rea classified as seleniferous or contaminated and where some bird eggs contain embryotoxic concentrations of selenium

$\boldsymbol{T}$ A rea classified as uncontaminated and where bird eggs do not contain embryotoxic concentrations of selenium

M A rea classified as seleniferous or contaminated but where bird eggs do not contain embryotoxic concentrations of selenium

Test areas and other areas or sites discussed in text:

West

Oakes

A rea or site where surface water is not selenium contaminated

Scofield

A rea or site where surface water is selenium contaminated 
The three areas classified as embryotoxic in table 2 that were not identified from the map are the Sun River area in Montana, the lower Colorado River valley in California and Arizona, and the Stillwater Wildlife Management Area in Nevada ( $X, J$, and $W$, table 2 ). Embryotoxicity in the Sun River area was not identified because of insufficient resolution of climatological data (see section "Accuracy and Precision of Maps"). The biological classification of the lower Colorado River valley as embryotoxic is not concordant with its classification as uncontaminated on the basis of waterborne selenium (table 2). The bird eggs were from a bird that feeds in backwater areas where circulation is minimal (William G. Kepner, U.S. Fish and Wildlife Service, written commun., 1989), whereas almost all the water samples were from the mainstem of the Colorado River, where selenium concentrations are typically 1 to $2 \mu \mathrm{g} / \mathrm{L}$. Water samples from these backwater areas, where evaporation can increase selenium concentrations to toxic levels, were not collected as part of the NIWQP. In the Stillwater Wildlife Management Area, all the embryotoxic sets of eggs were from two isolated sets of ponds. The source of selenium is not known; however, near the ponds are Pliocene sedimentary deposits that are interlayered with basalts and tuffs (Willden and Speed, 1974) and may be seleniferous because of their association with the volcanic material.

Three areas $(B, M$, and $P$, table 2$)$ were identified as susceptible from the map, but selenium concentrations in bird eggs were not embryotoxic. In these areas, however, sample sizes were inadequate to determine whether selenium contamination is a problem. Three or fewer sets of eggs were collected, and not enough birds of appropriate feeding guilds were available for sampling. Selenium concentrations in fish tissue from these areas were compared with values presented by Lemly (1995) to assess the potential for reproductive impairment in fish. In two of the three areas ( $B$ and $M)$, the hazard is high for selenium-induced reproductive impairment in some fish.

Deformities of birds directly attributable to selenium were found in 4 of the 12 embryotoxic areas $(F, H, N$, and $Y$, table 2) and the map identified all 4 as susceptible. The map cannot be tested by comparison with areas where no deformities were found. That deformities were not found in some areas does not mean that none occur. In some areas, no latestage embryos were examined for deformities, and some embryos examined were not from areas where selenium concentrations measured in eggs or water were high.

Figure 9. National Irrigation Water Quality Program study and test areas in relation to areas in Western United States that are identified as susceptible to irrigation-induced selenium contamination (fig. 8). For base credit, see figure 1.

\section{Comectness of Analysis}

The reliability of any map identifying areas susceptible to irrigation-induced selenium contamination depends on several factors. First, the analysis that is the basis for the map must be correct and complete; it cannot be based on incorrect or incomplete analysis of critical factors that cause irrigation-induced selenium contamination. Second, the most important factors must be mappable. Third, the reliability of the map depends on the accuracy and precision of the maps used to portray the distribution of the critical factors.

The basic assumptions for the map in figure 8 are that application of irrigation water mobilizes selenium only from soils derived from Upper Cretaceous or Tertiary marine sedimentary deposits and that subsequent evaporative enrichment is the principal factor that determines whether concentrations of selenium reach toxic levels. These assumptions are of fundamental importance because in some instances when they were not met, areas having known selenium problems could not be identified from the map.

In this report, areas are considered geologically susceptible to irrigation-induced selenium contamination only if the bedrock in the area consists of Upper Cretaceous or Tertiary marine sedimentary rocks or deposits. Thus, areas susceptible to selenium contamination would not be identified from figure 8 if the soils are derived from other seleniferous rocks. Upper Cretaceous marine sedimentary rocks were included because generally they are seleniferous and are widespread in the Western United States. Tertiary marine sedimentary deposits were included because they also may be seleniferous. Their inclusion does not greatly increase the amount of land that could be falsely identified as susceptible; even if they are not seleniferous, they are not widespread in arid areas of the Western United States. Tertiary continental sedimentary deposits were not included for several reasons. The occurrence of selenium in Tertiary continental sedimentary deposits is localized; not all are seleniferous. Because these rocks are very widespread their inclusion could greatly increase the amount of land falsely identified as susceptible to contamination.

In this report, areas are considered climatically susceptible to irrigation-induced selenium contamination only if the EI exceeds about 2.5. This value for EI is empirical and is based only an on analysis of conditions at the NIWQP study areas. Thus, susceptible areas would not be identified from figure 8 if selenium concentrations exceed water-quality criteria in areas of minimal or no subsequent evaporative enrichment. This may happen in areas where the soils are much more seleniferous than in areas studied by the NIWQP. 
TABLE 7. Reliability of map assessment of study-area susceptibility and interpolation of climatic variables

[C, contaminated; EI, evaporation index; FWSE, free-water surface evaporation; NIWQP, National Irrigation Water Quality Program; PRISM, precipitation-elevation regressions on independent slopes model; S, seleniferous; UC, uncontaminated; - , no data]

\begin{tabular}{|c|c|c|c|c|c|c|c|c|}
\hline \multirow{2}{*}{$\begin{array}{c}\text { Area } \\
\text { identifier }\end{array}$} & \multirow{2}{*}{ Study area } & \multirow{2}{*}{$\begin{array}{l}\text { Study-area } \\
\text { classification }{ }^{1}\end{array}$} & \multirow{2}{*}{$\begin{array}{c}\text { Map } \\
\text { assessment }\end{array}$} & \multicolumn{2}{|c|}{$\begin{array}{c}\text { Precipitation } \\
\text { (inches per year) }\end{array}$} & \multirow{2}{*}{$\begin{array}{c}\text { FWSE } \\
\text { rate }^{4} \\
\text { (inches }^{\text {per }} \\
\text { year) }\end{array}$} & \multicolumn{2}{|c|}{ EI } \\
\hline & & & & $\mathrm{Map}^{2}$ & Actual $^{3}$ & & $\mathrm{Map}^{5}$ & Actual $^{6}$ \\
\hline $\boldsymbol{A}$ & American Falls Reservoir, Idaho & $\mathrm{UC}$ & Correct & 11.2 & 10.9 & 41 & 3.7 & 3.7 \\
\hline$B$ & Angostura Reclamation Unit, South Dakota & $\mathrm{S}$ & Correct & 15 & 16.4 & 46 & 3.0 & 2.8 \\
\hline$D$ & Columbia River Basin, Washington & $\mathrm{UC}$ & Correct & 10 & 8 & 40 & 4.0 & 5.0 \\
\hline$E$ & Dolores-Ute Mountain area, Colorado & $\mathrm{C}$ & Correct & 14 & 12 & 53 & 4.0 & 4.4 \\
\hline $\boldsymbol{F}$ & Gunnison River Basin-Grand Valley Project, Colorado & $\mathrm{C}$ & Correct & 11.1 & 9.3 & 50 & 4.6 & 5.4 \\
\hline G & Humboldt River area, Nevada & $\mathrm{UC}$ & Correct & 10 & 5.5 & 45 & 4.5 & 8.1 \\
\hline$J$ & Lower Colorado River valley, California-Arizona & $\mathrm{UC}$ & Correct & 10 & 4.5 & 85 & 8.5 & 18.9 \\
\hline$K$ & Lower Rio Grande valley, Texas & $\mathrm{UC}$ & Correct & $\left({ }^{7}\right)$ & 25.9 & 57 & $\left({ }^{7}\right)$ & 2.2 \\
\hline$L$ & Malheur National Wildlife Refuge, Oregon & $\mathrm{UC}$ & Correct & 11.2 & 10 & 43 & 4.0 & 4.3 \\
\hline$M$ & Middle Arkansas River Basin, Colorado-Kansas & $\mathrm{C}$ & Correct & 13.4 & 14.6 & 58 & 4.3 & 4.0 \\
\hline$N$ & Middle Green River Basin, Utah & $\mathrm{C}$ & Correct & 10 & 7.6 & 43 & 4.2 & 5.7 \\
\hline 0 & Middle Rio Grande, New Mexico & $\mathrm{UC}$ & Correct & 10.4 & 9.4 & 64 & 6.2 & 6.8 \\
\hline $\boldsymbol{P}$ & Milk River Basin, Montana & $\mathrm{UC}$ & Incorrect & 15 & 12 & 40 & 2.7 & 3.3 \\
\hline $\boldsymbol{U}$ & Salton Sea area, California & $\mathrm{C}$ & Incorrect & 10 & 3 & 73 & 7.3 & 24.5 \\
\hline $\boldsymbol{v}$ & San Juan River area, New Mexico & $\mathrm{S}$ & Correct & 10 & 7.6 & 56 & 5.6 & 7.4 \\
\hline$w$ & Stillwater Wildlife Management Area, Nevada & $\mathrm{UC}$ & Correct & 10 & 5.3 & 53 & 5.2 & 10.0 \\
\hline$x$ & Sun River area, Montana & $\mathrm{C}$ & Incorrect & 18.9 & 12 & 36 & 1.9 & 3.0 \\
\hline $\boldsymbol{Y}$ & Tulare Lake Bed area, California & $\mathrm{C}$ & Correct & 10 & 5.5 & 61 & 6.3 & 11.1 \\
\hline$Z$ & Vermejo Project area, New Mexico & $\mathrm{C}$ & Correct & 15 & 13.8 & 54 & 3.6 & 3.9 \\
\hline
\end{tabular}

${ }^{1}$ Criteria used: uncontaminated (UC), 75th percentile of selenium concentrations in surface water is less than 3 micrograms per liter; seleniferous (S), 75th percentile is at least 3 but less than 5 micrograms per liter; contaminated (C), 75th percentile is at least 5 micrograms per liter. Avian effect level (Skorupa and Ohlendorf, 1991) is 3 micrograms per liter; chronic criterion for protection of freshwater aquatic life (U.S. Environmental Protection Agency, 1987) is 5 micrograms per liter.

${ }^{2}$ Mean annual precipitation for NIWQP data-collection sites as interpolated from PRISM data layer.

${ }^{3}$ Annual precipitation based on data in published reports of reconnaissance and detailed studies (table 1); where range of values was shown, value used here is midpoint of range.

${ }^{4}$ Mean annual evaporation for NIWQP data-collection sites as interpolated from FWSE data layer.

${ }^{5}$ Mean EI for NIWQP data-collection sites as interpolated from EI data layer.

${ }^{6}$ EI calculated by dividing FWSE values by actual annual precipitation.

${ }^{7}$ Precipitation and EI for this area were not estimated by using data layers because precipitation along coastal and international boundaries is modeled as 0 inch in PRISM data layer. 
In those areas, application of irrigation water may mobilize so much selenium that water-quality criteria are exceeded even though EI is less than 2.5, which is the minimum value used in figure 8 to identify susceptible areas.

Because EI is computed using mean annual precipitation and evaporation, the map shows susceptibility under average climatic conditions. During drought conditions or other periods of reduced water availability, selenium problems could develop in areas not identified from the map as being susceptible. Conversely, areas identified as susceptible may not have selenium problems during wetter than average periods.

\section{Accuracy and Precision of Maps}

The geologic map in figure 2 identifies areas of the Western United States underlain by potentially seleniferous bedrock and indicates areas where soils are likely to have been derived from seleniferous bedrock. The geology presented in figures 2 and 8 was derived from the King and Beikman (1974a) map, which was published at a scale of $1: 2,500,000$. The error inherent from that scale is equivalent to a radial distance of about 4,200 ft. The page-size maps in this report are at a scale of approximately 1:20,000,000. The error inherent from that scale is a distance of about 33,000 ft.

Compilation of the geologic map of the United States required much generalization. King and Beikman (1974b) described the process by which geologic units from larger scale maps were combined into broader map units and their contacts simplified to produce a pattern that is discernible at the scale of 1:2,500,000. At that scale, the minimum area that can be resolved is several square miles. Precisely locating contacts between geologic units is problematic because lines separating units on the geologic map are the equivalent of several hundred feet wide.

The King and Beikman (1974a) map is primarily a bedrock map and therefore does not show all surficial geology. Upper Cretaceous marine sedimentary rocks that form the bedrock are, in places, buried under much younger glacial deposits that blanket large parts of the northern interior States. (Such deposits are purposely not shown by King and Beikman.) Thus, seleniferous rocks of Cretaceous age may not be the parent material of the overlying soils in areas affected by Pleistocene glaciation even though they are mapped as being the bedrock.

For 22 of the 26 NIWQP study areas, EI values computed from the EI map are less than the actual values (table 7). Inaccuracy and imprecision in the EI map (fig. 6) are compounded by interpolating values between isograms on the GIS data layers of precipitation and evaporation. Errors from interpolation between isograms are largest where the contour intervals are large, the isograms are widely spaced, and no maximum or minimum values are shown.

For 13 of the study areas, the characteristics of the isohyets in the PRISM data layer result in overestimating annual precipitation by at least 20 percent (table 7 ). One type of error in interpolation results from widely spaced isohyets. For example, the Sun River area in Montana ( $X$, fig. 1 , table 2 ) is between the 10- and 20-inch isohyets. The actual annual precipitation in the area is about 12 inches, but precipitation for the area as computed by interpolation of the PRISM data layer is 18.9 inches (table 7). Similarly, a 20- inch isohyet forms a nearly closed loop around the Klamath Basin Refuge Complex (I, fig.1, table 2) area in California and Oregon and thus effectively isolates the area from the 10-inch isohyet. Consequently, annual precipitation in the area was computed as 20 inches, whereas actual precipitation is only about 13 inches.

Another type of error results from interpolation in morearid areas because the minimum isogram in the precipitation data layer is 10 inches per year. Precipitation values are estimated from the data layer as 10 inches per year for large areas of California, Arizona, and Nevada when in fact they are much less. Because of this type of error, interpolation results in EI values that are 50 to 70 percent too low for study areas such as the Salton Sea (Calif.) or Humboldt River (Nev.) areas ( $U$ and $G$, table 7 ), where the actual annual precipitation is 3 to 5 inches rather than 10 inches.

Errors that result from interpolating between isograms on the evaporation data layer are relatively smaller than those from the precipitation data layer. On the FWSE map, the contour interval is either 4 or 5 inches per year except in areas where the annual evaporation rate is greater than 80 inches. Furthermore, on the FWSE map the contour interval is about 10 percent of the values contoured. On the precipitation map, however, the contour interval is commonly the same as or greater than the values contoured.

The reliability of the map of susceptible areas is affected more by inaccuracy and imprecision in the climate map (fig. 6) than in the geologic map (fig. 2). Because the climate map commonly underestimates EI, the most likely type of error is a false negative - that is, identification of an area as not susceptible when in fact it is susceptible. The Sun River area in central Montana was incorrectly classified as not susceptible (table 7) because, although actual EI for the Sun River area is 3.0, EI computed from climatic data layers is 1.9. The parts of the map of susceptibility (fig. 8) most likely to be unreliable are along the boundaries between the white and grey areas. Large areas in central Montana and South Dakota may be more susceptible to irrigation-induced selenium contamination than are indicated in figure 8. 


\section{Land Use Within Susceptible Areas}

Because maps are visual, broad geographic areas susceptible to contamination can be identified easily. An additional advantage of maps is that overlays of land-use data can be created so that specific management areas that may have problems can be identified quickly.

Many Bureau of Reclamation projects are within areas mapped as susceptible to irrigation-induced selenium contamination (fig. 10). Some of these project areas have been investigated by the NIWQP. Maps showing locations of all DOI-managed areas and DOI trust lands could not be found. For example, maps showing all Indian Reservations where land is irrigated for agriculture could not be found.

A few National Wildlife Refuges are in susceptible areas (fig. 11); most are in areas that have been investigated by the NIWQP. The fact that only a few refuges are within susceptible areas, however, should not be taken as evidence that risk to wildlife in the Western United States is small. Many important wildlife habitats are not shown on the map. For example, in figure 11 only four National Wildlife Refuges are shown in Colorado, and none of the more than 200 Colorado Division of Wildlife areas (Colorado Division of Wildlife, 1980) are shown.

More than 66,400 square miles of land in the Western United States is irrigated for agricultural purposes. Derived in part from Earth Resources Observation System Data Center (1990) satellite imagery, figure 12 identifies all irrigated agricultural lands that are susceptible to contamination regardless of which Federal, State, local or private entity provides the water. About 4,100 square miles of irrigated land is within areas mapped as susceptible. In addition, large areas of irrigated land are adjacent to susceptible areas. More than 1,000 square miles of land in the western San Joaquin Valley is irrigated for agriculture (San Joaquin Valley Drainage Program, 1990), and much of that land is adjacent to areas identified as susceptible to irrigation-induced selenium contamination.

\section{DISC USSION AND SUMMARY}

In areas having local geologic sources of selenium, application of water to the soil mobilizes the selenium by dissolving it and creating hydraulic gradients that result in the discharge of seleniferous ground water into irrigation drains. Drain water can carry the selenium to areas used by wildlife, and, depending on the hydrology and climate of the area, toxic concentrations of selenium can result. Because selenium is toxic at very low concentrations, knowing where selenium contamination may occur is important so that appropriate measures can be taken to protect wildlife.
Upper Cretaceous marine sedimentary rocks are the most widespread seleniferous rocks in the Western United States. Selenium concentrations in water are elevated in all but 1 of the 12 NIWQP study areas where irrigated areas are on or adjacent to Upper Cretaceous marine sedimentary rocks. Research in the San Joaquin Valley in California has demonstrated that Tertiary marine sedimentary deposits upland from irrigated areas also can be important sources of selenium. The degree of contamination that results from mobilization of selenium by irrigation water depends greatly on the aridity and hydrology of the area.

A map was created using geologic and climatic information to identify areas in the Western United States susceptible to irrigation-induced selenium contamination. This map cannot be used to identify every area where irrigationinduced selenium contamination may be found because some important hydrologic factors, such as whether the area contains terminal ponds and whether selenium is brought into the area (for example, in water imported for irrigation), are not readily mapped. However, the map presented in this report, although based only on the geology and climate, does identify most of the NIWQP areas where irrigation-induced selenium contamination is known.

Conclusions that an area is not at risk on the basis of these maps should be examined critically if the soils and soilparent materials in the area are known to be very seleniferous. In such cases, nonarid areas that are not identified from the map as being susceptible to irrigation-induced selenium contamination because the EI is less than 2.5 may in fact be susceptible. In an area of very seleniferous soils, application of irrigation water could possibly result in such large amounts of selenium being mobilized that toxic concentrations occur even with very little evaporative enrichment. Further, the map is based on average climatic conditions, and problems may not occur during normal or wet years but could occur during drought years and other periods of reduced water availability.

The reliability of the maps could be improved if they were prepared from more-detailed or larger scale geologic and climatic maps. The susceptible areas in Montana, for example, could be identified better if a State map of precipitation, such as that by Parret and Omang (1986), were used. Creating a better national map of precipitation by compositing currently available State-scale maps is problematic. Because State maps are produced by many different agencies, different periods of record and precipitation contour intervals typically are used on maps of adjacent States. Furthermore, even if the contours were the same, laying maps of adjacent States next to each other does not mean that the contours will meet at the State boundaries. Similar problems would be encountered in an attempt to composite geology or other data from State-scale maps. 


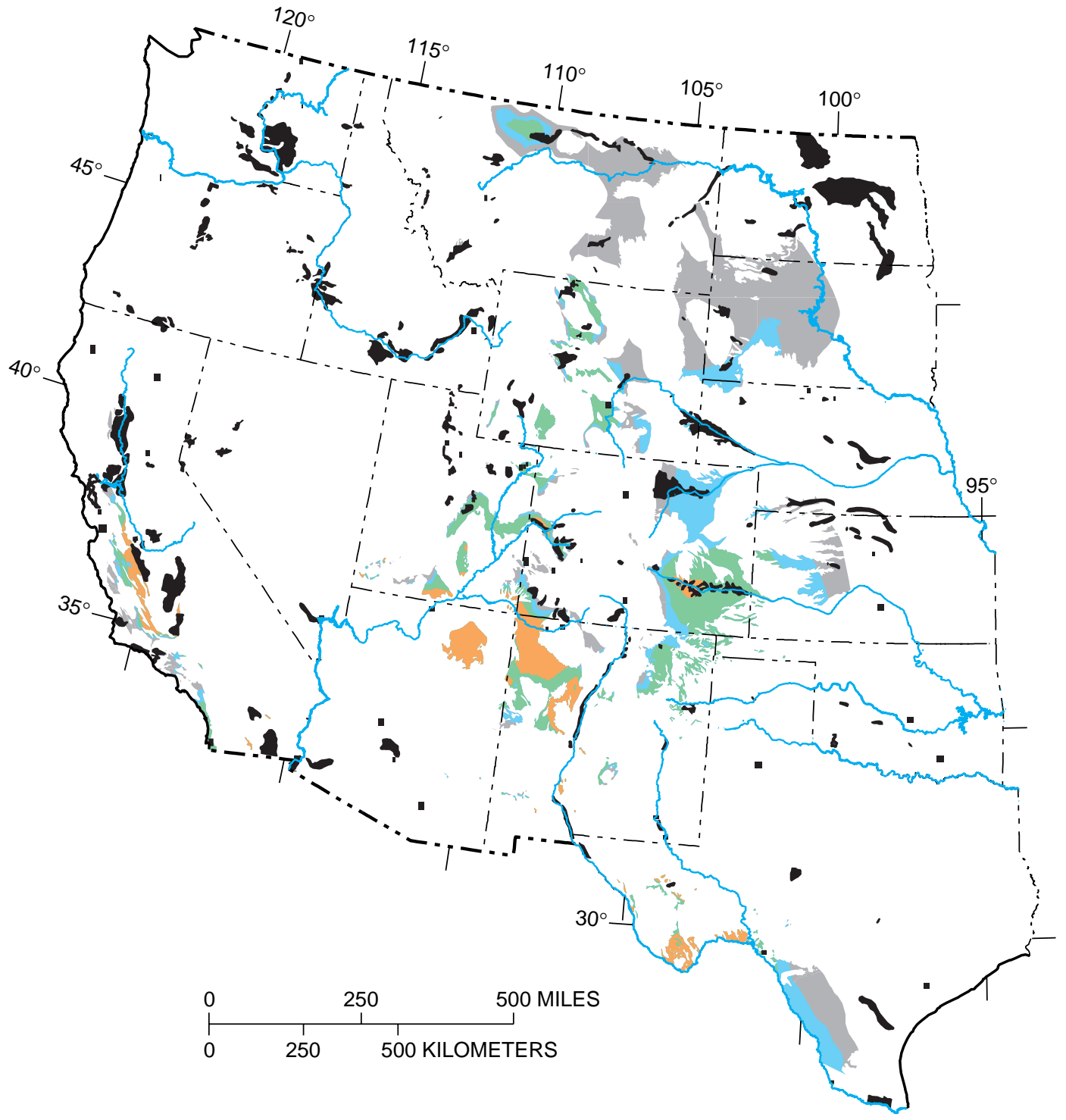

\section{EXPLANATION}

Evaporation index in areas where geologic units are mainly Upper Cretaceous or

Tertiary marine sedimentary deposits:

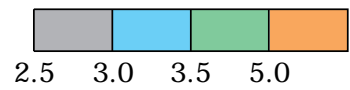

Bureau of Reclamation project area

Figure 10. Bureau of Reclamation (1988) project areas in relation to areas in Western United States that are identified as susceptible to irrigation-induced selenium contamination (fig. 8). For base credit, see figure 1. 


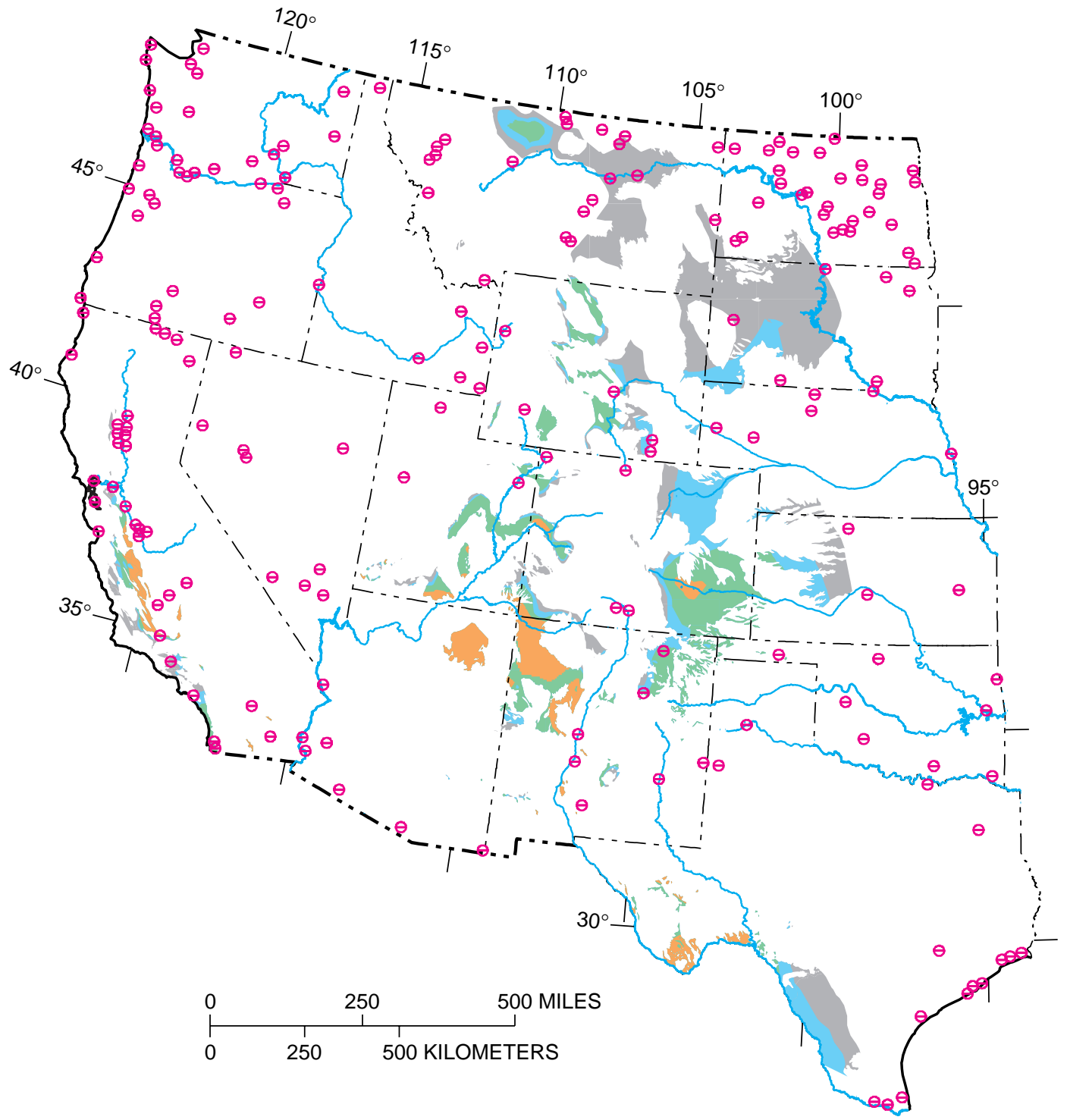

EXPLANATION

Evaporation index in areas where geologic units are mainly Upper Cretaceous or Tertiary marine sedimentary deposits:

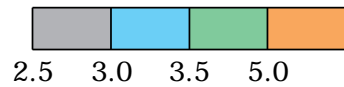

$\ominus \quad$ National Wildlife Refuge

Figure 11. National Wildlife Refuges (U.S. Fish and Wildlife Service, 1988) in relation to areas in Western United States that are identified as susceptible to irrigation-induced selenium contamination (fig. 8). For base credit, see figure 1. 


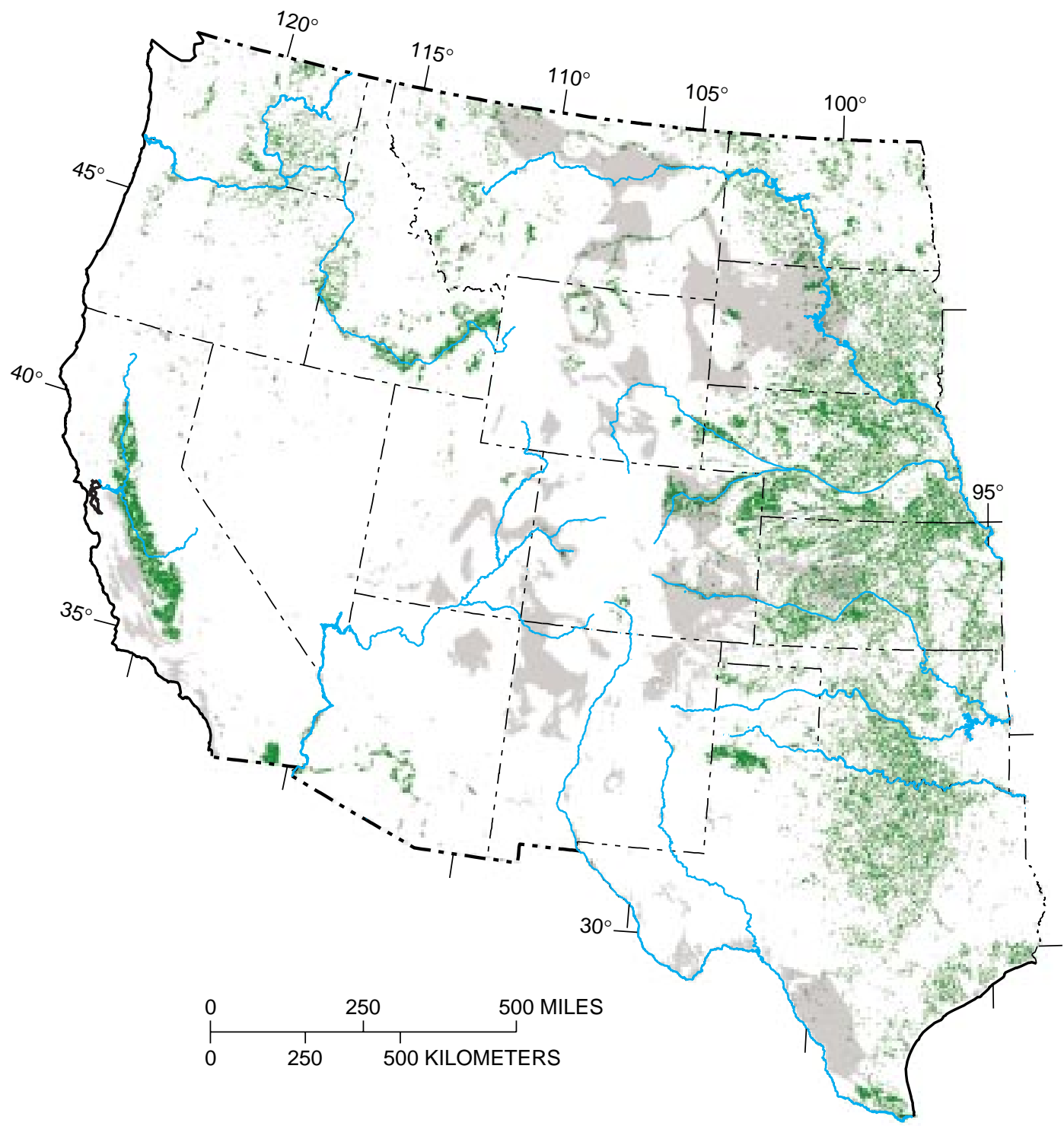

\section{EXPLANATION}

Area susceptible to contamination-Where evaporation index is greater than 2.5 and where geologic units are mainly U pper Cretaceous or Tertiary marine sedimentary deposits

Irrigated agricultural land

FIGURE 12. Irrigated agricultural lands in relation to areas in Western United States that are identified as susceptible to irrigation-induced selenium contamination (fig. 8). Irrigation data was derived in part from Earth Resources Observation System Data Center (1990) satellite images. For base credit, see figure 1. 
That the maps in this report identified all four NIWQP study areas where deformed embryos were found, and most of the areas where sets of bird eggs contained embryotoxic concentrations of selenium, demonstrates the biological significance of the map. Four NIWQP study areas are within areas mapped as susceptible, but embryotoxic concentrations of selenium were not observed in bird eggs. These sites may warrant sampling efforts that are more extensive, both taxonomically and spatially.

About 4,100 square miles of irrigated land in the Western United States was identified from maps as being susceptible to irrigation-induced selenium contamination. Large areas of irrigated agricultural land adjacent to areas identified as susceptible from the map are also at risk. The map presented here is intended to be used as a screening and ranking tool by managers. After ranking the likelihood of contamination in several areas, resources can be directed toward assessing selenium contamination in areas where it is most likely.

\section{REFERENCES C TED}

Bartolino, J.R., Garrabrant, L.A., Wilson, Mark, and Lusk, J.D., 1996, Reconnaissance investigation of water quality, bottom sediment, and biota associated with irrigation drainage in the Vermejo Project area and the Maxwell National Wildlife Refuge, Colfax County, northeastern New Mexico, 1993: U.S. Geological Survey Water-Resources Investigations Report 96-4157, $89 \mathrm{p}$.

Berrow, M.L., and Ure, A.M., 1989, Geological materials and soils, in Ihnat, M., ed., Occurrence and distribution of selenium: Boca Raton, Fla., CRC Press, p. 213-242.

Blanchard, P.J., Roy, R.R., and O'Brien, T.F., 1993, Reconnaissance investigation of water quality, bottom sediment, and biota associated with irrigation drainage in the San Juan River area, San Juan County, northwestern New Mexico, 1990-91: U.S. Geological Survey Water-Resources Investigations Report 93-4065, $141 \mathrm{p}$.

Bureau of Reclamation, 1981, Water and Power Resources Service-Project data: Washington, D.C., U.S. Government Printing Office, 1463 p.

1988, Western United States showing location of Bureau of Reclamation projects: Washington, D.C., U.S. Government Printing Office GPO 856-745, Map no. X-D-4151, scale $\sim 1: 5,850,000$.

Butler, D.L., Kreuger, R.P., Campbell-Osmundson, Barbara, and Jenson, E.G., 1995, Reconnaissance investigation of water quality, bottom sediment, and biota associated with irrigation drainage in the Dolores Project area, southwestern Colorado and southeastern Utah, 1990-91: U.S. Geological Survey Water-Resources Investigations Report 94-4041, 126 p.
Butler, D.L., Krueger, R.P., Osmundson, B.C., Thompson, A.L., Formea, J.J., and Wickman, D.W., 1993, Reconnaissance investigation of water quality, bottom sediment, and biota associated with irrigation drainage in the Pine River Project area, southern Ute Indian Reservation, southwestern Colorado and northwestern New Mexico, 1988-89: U.S. Geological Survey Water-Resources Investigations Report 92-4188, $105 \mathrm{p}$.

Butler, D.L., Krueger, R.P., Osmundson, B.C., Thompson, A.L., and McCall, S.K., 1991, Reconnaissance investigation of water quality, bottom sediment and biota associated with irrigation drainage in the Gunnison and Uncompahgre River Basins and at Sweitzer Lake, west-central Colorado, 1988-89: U.S. Geological Survey Water-Resources Investigations Report 91-4103, 99 p.

Butler, D.L., Wright, W.G., Hahn, D.A., Krueger, R.P., and Osmundson, B.C., 1994, Physical, chemical, and biological data for detailed study of irrigation drainage in the Uncompaghre Project area and in the Grand Valley, west-central Colorado, 1991-92: U.S. Geological Survey Open-File Report 94-110, $146 \mathrm{p}$.

Butler, D.L., Wright, W.G., Stewart, K.C., Osmundson, B.C., Krueger, R.P., and Crabtree, D.W., 1996, Detailed study of selenium and other constituents in water, bottom sediment, soil, alfalfa, and biota associated with irrigation drainage in the Uncompahgre Project area and in the Grand Valley, westcentral Colorado, 1991-93: U.S. Geological Survey WaterResources Investigations Report 96-4138, 136 p.

Byers, H.G., Williams, K.T., and Lakin, H.W., 1936, Selenium in Hawaii and its probable source in the United States: Industrial and Engineering Chemistry, v. 28, no. 7, p. 821-823.

Colorado Division of Wildlife, 1980, Guide to Colorado's State Wildlife Areas-A listing of 214 Division of Wildlife properties with 21 maps showing 37 selected State Wildlife Areas: Colorado Outdoors Magazine Publication, 32 p.

Daly, Christopher, Neilson, R.P., and Phillips, D.L., 1994, A statistical-topographic model for mapping climatological precipitation over mountainous terrain: Journal of Applied Meteorology, v. 33 , no. 2 , p. $140-158$.

Deason, J.P., 1986, U.S. Department of the Interior investigations of irrigation-induced contamination problems, in Summers, J.B., and Anderson, S.S., eds., Toxic substances in agricultural water supply and drainage-Defining the problems-Proceedings of regional meeting of the U.S. Committee on Irrigation and Drainage, September 1986, Boulder, Colo.: Washington, D.C., U.S. Government Printing Office, p. 201-210.

Dileanis, P.D., Schwarzbach, S.E., Bennett, Jewel, and others, 1996, Detailed study of water quality, bottom sediment, and biota associated with irrigation drainage in the Klamath Basin, California and Oregon, 1990-92: U.S. Geological Survey Water-Resources Investigations Report 95-4232, 68 p. 
Dileanis, P.D., Sorenson, S.K., Schwarzbach, S.E., and Maurer, T.C., 1992, Reconnaissance investigation of water quality, bottom sediment, and biota associated with irrigation drainage in the Sacramento National Wildlife Refuge Complex, California, 1988-89: U.S. Geological Survey Water-Resources Investigations Report 92-4036, 79 p.

Earth Resources Observation System Data Center, 1990, Prototype 1990 conterminous U.S. land-cover characteristics data set [CD-ROM]: U.S. Geological Survey, Earth Resources Observation System Data Center.

Embry, S.S., and Block, E.K., 1995, Reconnaissance investigation of water quality, bottom sediment, and biota associated with irrigation drainage in the Columbia Basin Project, Washington, 1991-92: U.S. Geological Survey Water-Resources Investigations Report 95-4007, 144 p.

Engberg, R.A., and Sylvester, M.A., 1993, Concentrations, distribution, and sources of selenium from irrigated lands in Western United States: Journal of Irrigation and Drainage Engineering, v. 119 , no. 3 , p. 522-536.

Farnsworth, R.K., Thompson, E.S., and Peck, E.L., 1982, Annual free water surface evaporation (shallow lake), 1956-70, in Evaporation atlas for the contiguous 48 United States: National Oceanic and Atmospheric Administration Technical Report NWS 33, map 3, scale 1:5,000,000.

Feltz, H.R., Engberg, R.A., and Sylvester, M.A., 1991, Reconnaissance investigations of the effects of irrigation drainage on water quality, bottom sediment, and biota in the Western United States, in Mallard, G.E., and Aronson, D.A., eds., U.S. Geological Survey Toxic Substances Hydrology Program-Proceedings of the technical meeting, Monterey, Calif., March 11-15, 1991: U.S. Geological Survey WaterResources Investigations Report 91-4034, p. 319-323.

Fujii, Roger, and Swain, W.C., 1995, Areal distribution of selected trace elements, salinity, and major ions in shallow ground water, Tulare Basin, southern San Joaquin Valley, California: U.S. Geological Survey Water-Resources Investigations Report 95-4048, 67 p.

Goolsby, D.A., Severson, R.C., Wilson, S.A., and Webber, K., 1989 , Geochemistry of soils and shallow ground water, with emphasis on arsenic and selenium, in part of the Garrison Diversion Unit, North Dakota, 1985-87: U.S. Geological Survey Water-Resources Investigations Report 89-4104, 132 p.

Grasso, D.N, Jennings, M.E., and Sadler, W.J., 1995, Field screening of water quality, bottom sediment, and biota associated with irrigation drainage, Wind River Indian Reservation, Wyoming, 1992-93: U.S. Geological Survey Open-File Report 95-121, 41 p.

Greene, E.A., Sowards, C.L., and Hansmann, E.W., 1990, Reconnaissance investigation of water quality, bottom sediment, and biota associated with irrigation drainage in the Angostura Reclamation Unit, southwestern South Dakota, 1988-89: U.S. Geological Survey Water-Resources Investigations Report 90-4152, $75 \mathrm{p}$.
Hallock, R.J., and Hallock, L.L., eds., 1993, Detailed study of irrigation drainage in and near wildlife management areas, westcentral Nevada, 1987-90_-Part B, Effect on biota in Stillwater and Fernley Wildlife Management Areas and other nearby wetlands: U.S. Geological Survey Water-Resources Investigations Report 92-4024-B, 84 p.

Helsel, D.R., and Cohn, T.A., 1988, Estimation of descriptive statistics for multiply censored water-quality data: Water Resources Research, v. 24, no. 12, p. 1997-2004.

Helsel, D.R., and Hirsch, R.M., 1992, Statistical methods in water resources: New York, Elsevier, 522 p.

Hoffman, D.J., and Heinz, G.H, 1988, Embryotoxic and teratogenic effects of selenium in the diet of mallards: Journal of Toxicology and Environmental Health, v. 24, p. 477-490.

Hoffman, D.J., Ohlendorf, H.M., and Aldrich, T.W., 1988, Selenium teratogenesis in natural populations of aquatic birds in central California: Archives of Environmental Contamination and Toxicology, v. 17, p. 519-525.

Hoffman, R.J., 1994, Detailed study of irrigation drainage in and near wildlife management areas, west-central Nevada, 198790-Part C, Summary of irrigation-drainage effects on water quality, bottom sediment, and biota: U.S. Geological Survey Water-Resources Investigations Report 92-4024-C, 32 p.

Hoffman, R.J., Hallock, R.J., Rowe, T.G., Lico, M.S., Burge, H.L., and Thompson, S.P., 1990, Reconnaissance investigation of water quality, bottom sediment, and biota associated with irrigation drainage in and near Stillwater Wildlife Management Area, Churchill County, Nevada, 1986-87: U.S. Geological Survey Water-Resources Investigations Report 89-4105, $150 \mathrm{p}$.

King, K.A., Custer, T.W., and Weaver, D.A., 1994, Reproductive success of barn swallows nesting near a selenium-contaminated lake in east Texas, USA: Environmental Pollution, v. 84 , p. 53-58.

King, P.B., and Beikman, H.M., 1974a, comps., Geologic map of the United States (exclusive of Alaska and Hawaii): U.S. Geological Survey, three sheets, scale 1:2,500,000.

1974b, Explanatory text to accompany the geologic map of the United States: U.S. Geological Survey Professional Paper 901,40 p.

Knapton, J.R., Jones, W.E., and Sutphin, J.W., 1988, Reconnaissance investigation of water quality, bottom sediment, and biota associated with irrigation drainage in the Sun River area, west-central Montana, 1986-87: U.S. Geological Survey Water-Resources Investigations Report 87-4244, 78 p.

Lakin, H.W., and Byers, H.G., 1941, Selenium occurrence in certain soils in the United States, with a discussion of related topics-Sixth report: U.S. Department of Agriculture Technical Bulletin 783, 27 p. 
Lambing, J.H., Jones, W.E., and Sutphin, J.W., 1988, Reconnaissance investigation of water quality, bottom sediment, and biota associated with irrigation drainage in the Bowdoin National Wildlife Refuge and adjacent areas of the Milk River Basin, northeastern Montana, 1986-87: U.S. Geological Survey Water-Resources Investigations Report 87-4243, 71 p.

Lambing, J.H., Nimick, D.A., Knapton, J.R., and Palawski, D.U., 1994, Physical, chemical, and biological data for detailed study of the Sun River Irrigation Project, Freezout Lake Wildlife Management Area, and Benton Lake National Wildlife Refuge, west-central Montana, 1990-92, with selected data for 1987-89: U.S. Geological Survey Open-File Report 94$120,171 \mathrm{p}$.

Lemly, A.D., 1985, Toxicology of selenium in a freshwater reservoir-Implications for environmental hazard evaluation and safety: Ecotoxicology and Environmental Safety, v. 10, p. 314-338.

1993, Subsurface agricultural irrigation drainage- The need for regulation: Regulatory Toxicology and Pharmacology, v. 17, p. 157-180.

1995, A protocol for aquatic hazard assessment of selenium: Ecotoxicology and Environmental Safety, v. 32, p. 280-288.

Lico, M.S., 1992, Detailed study of irrigation drainage in and near wildlife management areas, west-central Nevada, 1987-90Part A, Water quality, sediment composition, and hydrogeochemical processes in Stillwater and Fernley Wildlife Management Areas: U.S. Geological Survey Water-Resources Investigations Report 92-4024-A, 65 p.

Low, W.H., and Mullins, W.H., 1990, Reconnaissance investigations of water quality, bottom sediment, and biota associated with irrigation drainage in the American Falls Reservoir area, Idaho, 1988-89: U.S. Geological Survey Water-Resources Investigations Report 90-4120, 78 p.

MacCoy, D.E., 1994, Physical, chemical, and biological data for detailed study of irrigation drainage in the Klamath Basin, California and Oregon, 1990-92: U.S. Geological Survey Open-File Report 93-497, 168 p.

Moore, S.B., Winckel, J., Detwiler, S.J., Klasing, S.A., Gaul, P.A., Kanim, N.R., Kesser, B.E., DeBevec, A.B., Beardsley, K., and Puckett, L.K., 1990, Fish and wildlife resources and agricultural drainage in the San Joaquin Valley, California: Sacramento, Calif., San Joaquin Valley Drainage Program, 2 v.

Moxon, A.L., Olson, O.E., and Searight, W.V., 1939, Selenium in rocks, soils, and plants: South Dakota Agricultural Experiment Station Technical Bulletin, v. 2, 94 p.

Mueller, D.K., DeWeese, L.R., Garner, A.J., and Spruill, T.B., 1991, Reconnaissance investigation of water quality, bottom sediment, and biota associated with irrigation drainage in the Middle Arkansas River Basin, Colorado and Kansas, 198889: U.S. Geological Survey Water-Resources Investigations Report 91-4060, 84 p.
Nebert, D.D., 1994, Design of the distributed spatial-data library (DSDL) for the Water Resources Division, U.S. Geological Survey: U.S. Geological Survey Open-File Report 94-327, 27 p.

Nimick, D.A., Lambing, J.H., Palawski, D.U., and Malloy, J.C., 1996, Detailed study of selenium in soil, water, bottom sediment, and biota in the Sun River Irrigation Project, Freezout Lake Wildlife Management Area, and Benton Lake National Wildlife Refuge, west-central Montana, 1990-92: U.S. Geological Survey Water-Resources Investigations Report 954170, $120 \mathrm{p}$.

Ohlendorf, H.M., 1989. Bioaccumulation and effects of selenium in wildlife, in Jacobs, L.W., ed., Selenium in agriculture and the environment: Madison, Wisc., American Society of Agronomy and Soil Science Society of America Special Publication 23, p. 133-177.

Ohlendorf, H.M., Hoffman, D.J., Saiki, M.K., and Aldrich, T.W., 1986, Embryonic mortality and abnormalities of aquatic birds-Apparent impact of selenium from irrigation drainwater: Science of the Total Environment, v. 52, p. 49-63.

Ohlendorf, H.M., Kilness, A.W., Simmons, J.L., Stroud, R.K., Hoffman, D.J., and Moore, J.F., 1988, Selenium toxicosis in wild aquatic birds: Journal of Toxicology and Environmental Health, v. 24, p. 67-92.

Ohlendorf, H.M., Skorupa, J.P., Saiki, M.K., and Barnum, D.A., 1993, Food-chain transfer of trace elements to wildlife, in Allen, R.G., and Neale, C.M.U., eds., Management of irrigation and drainage systems-Integrated perspectives: New York, American Society of Civil Engineers, p. 596-603.

Ong, Kim, O'Brien, T.F., and Rucker, M.D., 1992, Reconnaissance investigation of water quality, bottom sediment, and biota associated with irrigation drainage in the middle Rio Grande valley and Bosque del Apache National Wildlife Refuge, New Mexico, 1988-89: U.S. Geological Survey Water-Resources Investigations Report 91-4036, 113 p.

Owenby, J., Heim, R., Jr., Burgin, M., and Ezell, D., 1992, Climatography of the United States-Maps of annual 1961-90 normal temperature, precipitation, and degree days, in Supplement no. 3, 1961-90 normal mean annual precipitation: Ashville, N.C., National Oceanic and Atmospheric Administration National Climatic Data Center, map 81, scale $1: 5,600,000$.

Parret, Charles, and Omang, R.J., 1986, Montana surface-water resources, in U.S. Geological Survey, 1986, National water summary 1985-Hydrologic events and surface-water resources: U.S. Geological Survey Water-Supply Paper 2300, p. 309-314.

Peltz, L.A., and Waddell, Bruce, 1991, Physical, chemical, and biological data for detailed study of irrigation drainage in the middle Green River Basin, Utah, 1988-89, with selected data for 1982-87: U.S. Geological Survey Open-File Report 91-530, $213 \mathrm{p}$. 
Peterson, D.A., Harms, T.F., Ramirez, P., Jr., Allen, G.T., and Christenson, A.H., 1991, Reconnaissance investigation of water quality, bottom sediment, and biota associated with irrigation drainage in the Riverton Reclamation Project, Wyoming, 1988-89: U.S. Geological Survey Water-Resources Investigations Report 90-4187, 84 p.

Peterson, D.A., Jones, W.E., and Morton, A.G., 1988, Reconnaissance investigation of water quality, bottom sediment, and biota associated with irrigation drainage in the Kendrick Reclamation Project area, Wyoming, 1986-87: U.S. Geological Survey Water-Resources Investigations Report 87-4255, 57 p.

Piper, D.Z., and Isaacs, C.M., 1995, Geochemistry of minor elements in the Monterey Formation, California-Seawater chemistry of deposition: U.S. Geological Survey Professional Paper 1566, 41 p.

Presser, T.S., 1994a, Geologic origin and pathways of selenium from the California coast ranges to the west-central San Joaquin Valley, in Frankenberger, W.T., Jr., and Benson, Sally, eds., Selenium in the environment: New York, Marcel Dekker, Inc., p. 139-155.

1994b, "The Kesterson effect": Environmental Management, v. 18 , no. 3 , p. 437-454.

Presser, T.S., Sylvester, M.A., and Low, W.H., 1994, Bioaccumulation of selenium from natural geologic sources in the Western United States and its potential consequences: Environmental Management, v. 18, no. 3, p. 423-436.

Radtke, D.B., Kepner, W.G., and Effertz, R.J., 1988, Reconnaissance investigation of water quality, bottom sediment, and biota associated with irrigation drainage in the lower Colorado River valley, Arizona, California, and Nevada, 1986-87: U.S. Geological Survey Water-Resources Investigations Report 88-4002, 77 p.

Rea, Alan, and Cederstrand, J.R., 1994, GCIP reference data set (GREDS) [CD-ROM]: U.S. Geological Survey Open-File Report 94-388.

Rinella, F.A., Mullins, W.H., and Schuler, C.A., 1994, Reconnaissance investigation of water quality, bottom sediment, and biota associated with irrigation drainage in the Owyhee and Vale Projects, Oregon and Idaho, 1990-91: U.S. Geological Survey Water-Resources Investigations Report 93-4156, $101 \mathrm{p}$.

Rinella, F.A., and Schuler, C.A., 1992, Reconnaissance investigation of water quality, bottom sediment, and biota associated with irrigation drainage in the Malheur National Wildlife Refuge, Harney County, Oregon, 1988-89: U.S. Geological Survey Water-Resources Investigations Report 91-4085, 106 p.

Roddy, W.R., Greene, E.A., and Sowards, C.L., 1991, Reconnaissance investigation of water quality, bottom sediment, and biota associated with irrigation drainage in the Bell Fourche Reclamation Project, western South Dakota, 1988-89: U.S. Geological Survey Water-Resources Investigations Report 90-4192, 113 p.
Rowe, T.G., Lico, M.S., Hallock, R.J., Maest, A.S., and Hoffman, R.J., 1991, Physical, chemical, and biological data for detailed study of irrigation drainage in and near Stillwater, Fernley, and Humboldt Wildlife Management Areas and Carson Lake, west-central Nevada, 1987-89: U.S. Geological Survey OpenFile Report 91-185, 199 p.

San Joaquin Valley Drainage Program, 1990, A management plan for agricultural subsurface drainage and related problems on the westside San Joaquin Valley: San Joaquin Valley Drainage Program, U.S. Department of the Interior and California Resources Agency, 183 p.

Schroeder, R.A., Palawski, D.U., and Skorupa, J.P., 1988, Reconnaissance investigation of water quality, bottom sediment, and biota associated with irrigation drainage in the Tulare Lake Bed area, southern San Joaquin Valley, California, 1986-87: U.S. Geological Survey Water-Resources Investigations Report 88-4001, 86 p.

Schroeder, R.A., Rivera, Mick, and others, 1993, Physical, chemical, and biological data for detailed study of irrigation drainage in the Salton Sea area, California, 1988-90: U.S. Geological Survey Open-File Report 93-83, 179 p.

Schruben, P.G., Arndt, R.E., and Bawiec, W.J., 1994, Geology of the conterminous United States at 1:2,500,000 scale-A digital representation of the 1974 P.B. King and H.M. Beikman map [CD-ROM]: U.S. Geological Survey Digital Data Series DDS-11.

See, R.B., Naftz, D.L., Peterson, D.A., Crock, J.G., Erdman, J.A., Severson, R.C., Ramirez, P., Jr., and Armstrong, J.A., 1992, Detailed study of selenium in soil, representative plants, water, bottom sediment, and biota in the Kendrick Reclamation Project area, Wyoming, 1988-90: U.S. Geological Survey Water-Resources Investigations Report 91-4131, 142 p.

See, R.B., Peterson, D.A., and Ramirez, P., Jr., 1992, Physical, chemical, and biological data for detailed study of irrigation drainage in the Kendrick Reclamation Project area, Wyoming, 1988-90: U.S. Geological Survey Open-File Report 91-533, $272 \mathrm{p}$.

Seiler, R.L, 1995, Prediction of areas where irrigation drainage may induce selenium contamination of water: Journal of Environmental Quality, v. 24, no. 5, p. 973-979.

1996, Synthesis of data from studies by the National Irrigation Water Quality Program: Water Resources Bulletin, v. 32, no. 6, p. 1233-1245.

Seiler, R.L., Ekechukwu, G.A., and Hallock, R.J., 1993, Reconnaissance investigation of water quality, bottom sediment, and biota associated with irrigation drainage in and near Humboldt Wildlife Management Area, Churchill and Pershing Counties, Nevada, 1990-91: U.S. Geological Survey Water-Resources Investigations Report 93-4072, 115 p. 
Setmire, J.G., Schroeder, R.A., Densmore, J.N., Goodbred, S.L., Audet, D.J., and Radke, W.R., 1993, Detailed study of water quality, bottom sediment, and biota associated with irrigation drainage in the Salton Sea area, California, 1988-90: U.S. Geological Survey Water-Resources Investigations Report 93-4014, 102 p.

Setmire, J.G., Wolfe, J.C., and Stroud, R.K., 1990, Reconnaissance investigation of water quality, bottom sediment, and biota associated with irrigation drainage in the Salton Sea area, California, 1986-87: U.S. Geological Survey Water-Resources Investigations Report 89-4102, 68 p.

Skorupa, J.P., 1998, Selenium poisoning of fish and wildlifeLessons from twelve real-world examples, in Frankenberger, W.T., Jr., and Engberg, R.A., Environmental chemistry of selenium: New York, Marcel Dekker, p. 315-354.

Skorupa, J.P., and Ohlendorf, H.M., 1991, Contaminants in drainage water and avian risk thresholds, in Dinar, Ariel, and Zilberman, David, eds., The economics and management of water and drainage in agriculture: Boston, Kluwer Academic Publishers, p. 345-368.

Sorenson, S.K., and Schwarzbach, S.E., 1991, Reconnaissance investigation of water quality, bottom sediment, and biota associated with irrigation drainage in the Klamath Basin, California and Oregon, 1988-89: U.S. Geological Survey Water-Resources Investigations Report 90-4203, 64 p.

Stephens, D.W., Waddell, Bruce, BuBois, Kristi, and Peterson, Elise, 1997, Field screening of water quality, bottom sediment, and biota associated with the Emery and Scofield Project areas, central Utah, 1994, U.S. Geological Survey WaterResources Investigations Report 96-4298, 39 p.

Stephens, D.W., Waddell, Bruce, and Miller, J.B., 1988, Reconnaissance investigation of water quality, bottom sediment, and biota associated with irrigation drainage in the middle Green River Basin, Utah, 1986-87: U.S. Geological Survey WaterResources Investigations Report 88-4011, 70 p.

Stephens, D.W., Waddell, Bruce, Peltz, L.A., and Miller, J.B., 1992, Detailed study of selenium and selected elements in water, bottom sediment, and biota associated with irrigation drainage in the middle Green River Basin, Utah, 1988-90: U.S. Geological Survey Water-Resources Investigations Report 924084, 164 p.

Sylvester, M.A., Deason, J.P., Feltz, H.R., and Engberg, R.A., 1988, Preliminary results of the Department of the Interior's irrigation-drainage studies, in Hay, D.R., ed., Planning now for irrigation and drainage-Proceedings of the American Society of Civil Engineers Irrigation Division meeting, July 18-21, 1988, Lincoln, Neb.: [Lincoln, Neb.], American Society of Civil Engineers, p. 655-677.

Tanji, Kenneth, Läuchli, André, and Meyer, Jewell, 1986, Selenium in the San Joaquin Valley: Environment, v. 28, no. 6, p. 6-39.
Thodal, C.E., and Tuttle, P.L., 1996, Field screening of water quality, bottom sediment, and biota associated with irrigation drainage in and near Walker River Indian Reservation, Nevada, 1994-95: U.S. Geological Survey Water-Resources Investigations Report 96-4214, 39 p.

Thomas, C.L., Lusk, J.D., Bristol, R.S., Wilson, R.M., and Shineman, A.R., 1997, Physical, chemical, and biological data for detailed study of irrigation drainage in the San Juan River area, New Mexico, 1993-94, with supplemental data, 199195: U.S. Geological Survey Open-File Report 97-249, 227 p.

Tidball, R.R., Severson, R.C., Presser, T.S., and Swain, W.C., 1991, Selenium sources in the Diablo Range, western Fresno County, California, in Severson, R.C., Fisher, S.E., Jr., and Gough, L.P., eds., Proceedings of the 1990 Billings Land Reclamation Symposium on Selenium in Arid and Semiarid Environments, Western United States: U.S. Geological Survey Circular 1064, p. 107-114.

Trelease, S.F., and Beath, O.A., 1949, Selenium, its geological occurrence and its biological effects in relation to botany, chemistry, agriculture, nutrition, and medicine: Burlington, Vt., Champlain Printers, 292 p.

U.S. Environmental Protection Agency, 1987, Ambient water-quality criteria for selenium-1987: Washington, D.C., Report EPA-440/5-87-006, 121 p.

U.S. Fish and Wildlife Service, 1988, National Wildlife RefugesA visitor's guide [pamphlet]: Washington, D.C., U.S. Government Printing Office, GPO 193-006.

Wells, F.C., Jackson, G.A., and Rogers, W.J., 1988, Reconnaissance investigation of water quality, bottom sediment, and biota associated with irrigation drainage in the lower Rio Grande valley and Laguna Atascosa National Wildlife Refuge, Texas, 1986-87: U.S. Geological Survey Water-Resources Investigations Report 87-4277, 89 p.

Willden, Ronald, and Speed, R.C., 1974, Geology and mineral deposits of Churchill County, Nevada: Nevada Bureau of Mines and Geology Bulletin 83, 95 p. 


\section{Selected Series of U.S. Geological Survey Publications}

\section{Books and Other Publications}

Professional Papers report scientific data and interpretations of lasting scientific interest that cover all facets of USGS investigations and research.

Bulletins contain significant data and interpretations that are of lasting scientific interest but are generally more limited in scope or geographic coverage than Professional Papers.

Water-Supply Papers are comprehensive reports that present significant interpretive results of hydrologic investigations of wide interest to professional geologists, hydrologists, and engineers. The series covers investigations in all phases of hydrology, including hydrogeology, availability of water, quality of water, and use of water.

Circulars are reports of programmatic or scientific information of an ephemeral nature; many present important scientific information of wide popular interest. Circulars are distributed at no cost to the public.

Fact Sheets communicate a wide variety of timely information on USGS programs, projects, and research. They commonly address issues of public interest. Fact Sheets generally are two or four pages long and are distributed at no cost to the public.

Reports in the Digital Data Series (DDS) distribute large amounts of data through digital media, including compact discread-only memory (CD-ROM). They are high-quality, interpretive publications designed as self-contained packages for viewing and interpreting data and typically contain data sets, software to view the data, and explanatory text.

Water-Resources Investigations Reports are papers of an interpretive nature made available to the public outside the formal USGS publications series. Copies are produced on request (unlike formal USGS publications) and are also available for public inspection at depositories indicated in USGS catalogs.

Open-File Reports can consist of basic data, preliminary reports, and a wide range of scientific documents on USGS investigations. Open-File Reports are designed for fast release and are available for public consultation at depositories.

\section{Maps}

Geologic Quadrangle Maps (GQ's) are multicolor geologic maps on topographic bases in 7.5- or 15-minute quadrangle formats (scales mainly 1:24,000 or 1:62,500) showing bedrock, surficial, or engineering geology. Maps generally include brief texts; some maps include structure and columnar sections only.

Geophysical Investigations Maps (GP's) are on topographic or planimetric bases at various scales. They show results of geophysical investigations using gravity, magnetic, seismic, or radioactivity surveys, which provide data on subsurface structures that are of economic or geologic significance.
Miscellaneous Investigations Series Maps or Geologic Investigations Series (I's) are on planimetric or topographic bases at various scales; they present a wide variety of format and subject matter. The series also incudes 7.5-minute quadrangle photogeologic maps on planimetric bases and planetary maps.

\section{Information Periodicals}

Metal Industry Indicators (MII's) is a free monthly newsletter that analyzes and forecasts the economic health of five metal industries with composite leading and coincident indexes: primary metals, steel, copper, primary and secondary aluminum, and aluminum mill products.

Mineral Industry Surveys (MIS's) are free periodic statistical and economic reports designed to provide timely statistical data on production, distribution, stocks, and consumption of significant mineral commodities. The surveys are issued monthly, quarterly, annually, or at other regular intervals, depending on the need for current data. The MIS's are published by commodity as well as by State. A series of international MIS's is also available.

Published on an annual basis, Mineral Commodity Summaries is the earliest Government publication to furnish estimates covering nonfuel mineral industry data. Data sheets contain information on the domestic industry structure, Government programs, tariffs, and 5-year salient statistics for more than 90 individual minerals and materials.

The Minerals Yearbook discusses the performance of the worldwide minerals and materials industry during a calendar year, and it provides background information to assist in interpreting that performance. The Minerals Yearbook consists of three volumes. Volume I, Metals and Minerals, contains chapters about virtually all metallic and industrial mineral commodities important to the U.S. economy. Volume II, Area Reports: Domestic, contains a chapter on the minerals industry of each of the 50 States and Puerto Rico and the Administered Islands. Volume III, Area Reports: International, is published as four separate reports. These reports collectively contain the latest available mineral data on more than 190 foreign countries and discuss the importance of minerals to the economies of these nations and the United States.

\section{Permanent Catalogs}

"Publications of the U.S. Geological Survey, 1879-1961" and "Publications of the U.S. Geological Survey, 19621970" are available in paperback book form and as a set of microfiche.

"Publications of the U.S. Geological Survey, 1971-1981" is available in paperback book form (two volumes, publications listing and index) and as a set of microfiche.

Annual supplements for 1982, 1983, 1984, 1985, 1986, and subsequent years are available in paperback book form. 

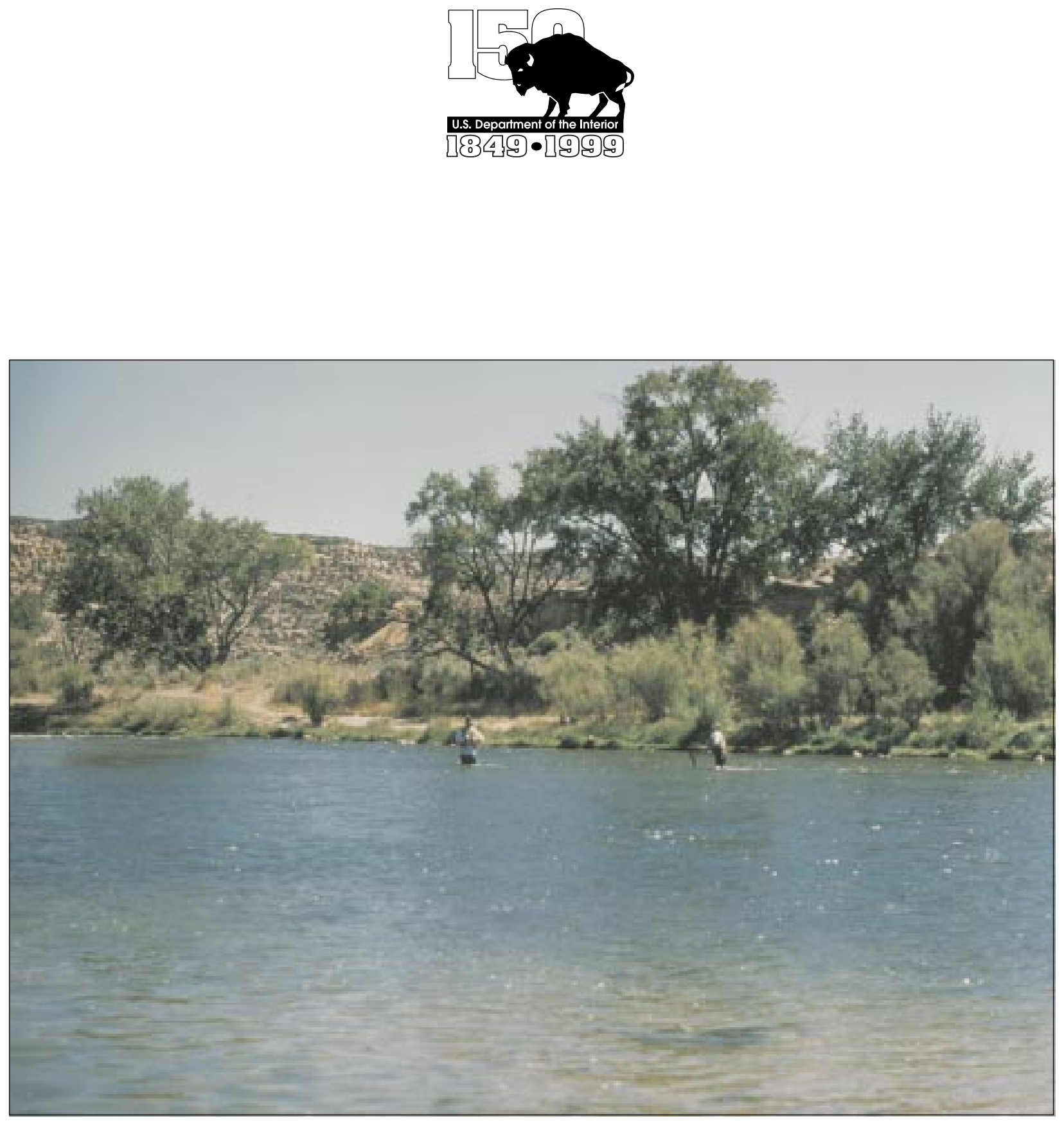

The San Juan River in northwestern New Mexico, like other rivers in the Western United States, provides water for recreation, wildlife, and agricultural use. Photograph by Carole L. Thomas, U.S. Geological Survey, 1993 